\title{
Effects of Alexandrium minutum exposure on nutrition-related processes and reproductive output in oysters Crassostrea gigas
}

\author{
Hansy Haberkorn ${ }^{a}$, Christophe Lambert ${ }^{\mathrm{a}}$, Nelly Le Goïc ${ }^{\mathrm{a}}$, Jeanne Moal ${ }^{\mathrm{b}}$, Marc Suquet ${ }^{\mathrm{c}}$, Marielle \\ Guéguen $^{\mathrm{d}}$, Inke Sunila ${ }^{\mathrm{e}}$ and Philippe Soudant ${ }^{\mathrm{a},{ }^{,}}$
}

\footnotetext{
${ }^{a}$ CNRS, Laboratoire des Sciences de l'Environnement Marin, Institut Universitaire Européen de la Mer, Université de Bretagne Occidentale, Place Copernic, Technopôle Brest-Iroise, 29280 Plouzané, France

${ }^{\mathrm{b}}$ Ifremer Centre de Brest, Laboratoire de Physiologie des Invertébrés, BP 70, 29280 Plouzané, France

${ }^{\mathrm{c}}$ Ifremer Station Expérimentale d'Argenton, Laboratoire de Physiologie des Invertébrés, 29840 Argenton, France

d Ifremer Centre de Nantes, Laboratoire Phycotoxines, BP 21105, 44311 Nantes, France

e Department of Agriculture, Bureau of Aquaculture, P.O. Box 97, Milford, CT 06460, USA
}

*: Corresponding author: Philippe Soudant, Tel.: +33 2984986 23; fax: +33 2984986 45, email address : soudant@univ-brest.fr

\begin{abstract}
:
This study assessed the effects of an artificial bloom of the toxin-producing dinoflagellate, Alexandrium minutum, upon nutrition related processes and reproductive output of the Pacific oyster, Crassostrea gigas. Oysters were exposed to A. minutum, Paralytic Shellfish Toxins (PST) producer and compared to a control batch of oysters fed Isochrysis galbana clone Tahitian (T.Iso). The experiment was performed in June 2008, when oysters were found ripe. Several physiological variables of oysters, such as PSTs accumulation, digestive gland and histological observations as well as spermatozoa quality, were measured at the end of the exposure. Results indicate that the digestive gland was greatly impacted upon A. minutum exposure. Monoacylglycerol and diacylglycerol contents as well as phospholipids (mainly phosphatidylcholine) drastically decreased in the digestive gland of oysters exposed to A. minutum compared to control oysters. At the same time, many oysters exposed to the harmful microalga presented a strong inflammatory response in different tissues of the digestive gland: in intestine as well as in digestive ducts and tubules. Spermatozoa in oysters exposed to A. minutum were morphologically and functionally modified compared to spermatozoa of control oysters. Indeed, spermatozoa were less motile and had lower ATP content in oysters exposed to A. minutum. Meanwhile, spermatozoa produced by control oysters showed higher percentage of mortality and relative DNA content than those produced by $A$. minutum exposed oysters. Finally, the characteristics of the mitochondria of spermatozoa also appeared to be modified upon $A$. minutum exposure. The results of this study suggests that an exposure of oysters to $A$. minutum, reducing energy status and motility of spermatozoa associated to morphological changes at the cellular and sub-cellular levels, can have consequences on spermatozoa fertility and reproduction success.
\end{abstract}

Keywords: Harmful algae; Alexandrium minutum; Oyster; Nutrition-related processes; Reproductive output 


\section{Introduction}

Among harmful algae, Alexandrium species have worldwide distribution, and some species have caused many PST-related events (Kim et al., 2005). The dinoflagellate A. minutum was observed in several countries in the world (North America, Australia, Taiwan, New Zealand and Jamaica for example) and in Europe, such as Spain, Ireland, Italy, Greece and France (Lilly et al., 2005; Ignatides et al., 2007; Ranston et al., 2007). Moreover, this species was known to produce Paralytic Shellfish Toxins (PSTs). Several commercial bivalve species, such as oysters, are known to accumulate PSTs by feeding on PST-producing microalgae(Oshima et al., 1990; Bricelj and Shumway, 1998). Mode of action of PSTs involved a reversible and highly specific block of ion transport by the sodium channel and thus of the action potential in excitable membranes (nerve and muscle fibers) (Narahashi, 1988; Bricelj and Shumway, 1998). Aductor-muscle paralysis of oysters, Crassostrea virginica (Gmelin, 1791), exposed to cultured Alexandrium fundyense (Balech, 1985) was observed by Hégaret et al. (2007). Alexandrium exposure is also known to have a negative impact on filtration and ingestion in bivalves (Bardouil et al., 1993; Wildish et al., 1998; Lassus et al., 1999; Li et al., 2001; Navarro et al., 2008). Inhibition of clearance was observed as the initial feeding response of Crassostrea gigas (Thunberg, 1793) exposed to $A$. tamarense (Lebour, 1925) and $A$. fundyense (Wildish et al., 1998). Similarly, Lassus et al. (1999) observed that exposing oysters, C. gigas, to cultured A. minutum (Halim, 1960) induced significant inhibition of shell-valve activity and clearance, filtration, and biodeposition rates. Exposure of bivalves to harmful microalgae can also affect digestion and energy allocation. Li et al. (2002) assessed the effects of $A$. tamarense on the energy budget, quantified as scope for 
growth (SFG), of the mussel, Perna viridis (Linnaeus, 1758), and the manila clam, Ruditapes philippinarum (Adams and Reeve, 1850). This study demonstrated that increase in PST burden was associated with significant reduction of SFG in both clams and mussels, primarily because of decreases in absorption efficiency (Li et al., 2002). This reduction in SFG can hypothetically be linked to modification of digestive metabolism (Fernandez-Reiriz, 2008). Also, a recent study (Haberkorn et al., in press) demonstrated that reserve lipids in digestive glands of $C$. gigas are modified upon exposure to A. minutum. Free fatty acid, monoacylglycerol, and diacylglycerol contents, as well as the ratio of reserve lipids (triacylglycerol, ether glycerides and sterol esters) to structural lipids (sterols), decreased significantly in digestive glands of oysters exposed to A. minutum compared to oysters fed a nutritious, control diet of Isochrysis sp. (Haberkorn et al., in press).

Some recent studies have described inflammatory responses (aggregation/infiltration of hemocytes in organs and/or hemocytes in diapedesis through epithelia) in different tissues of bivalve species exposed to several harmful microalgae (Galimany et al., 2008 a, b and c; Hégaret et al., 2009). Mussels (Mytilus edulis - Linnaeus, 1758) exposed to A. fundyense showed an inflammatory response consisting of diapedesis of hemocytes into the alimentary canal and hemocyte migration into the connective tissue between the gonadal follicles (Galimany et al., 2008a). These findings suggest that harmful-algal exposure can elicit activation of defense or repair mechanisms in response to resulting tissue lesions in bivalves.

Also, according to Galimany et al. (2008a, b and c) and Hégaret et al. (2009), the digestive gland is generally the organ most-affected by HAB exposure. Thus, as the structure of the digestive gland is often observed to be drastically modified, it appears pertinent to study the structural components of cell membranes in the digestive gland. Phospholipids and sterols are essential structural components of all cell membranes and may be used as markers of membrane modifications. Phospholipid alterations may occur through the oxidation of these labile molecules. Moreover, inflammatory responses are known to be induced by lipid oxidation in vertebrate models (reviewed in Fantone and Ward, 1982). In mussels (M. edulis) exposed to A. fundyense, increased ceroidosis in tissues was probably attributable to lipid peroxidation generated by ingestion of the harmful alga (Galimany et al., 2008a). Concurrently, an inflammatory response was observed in the mussel alimentary canal (Galimany et al., 2008a). These findings suggested a possible link between changes in digestive-gland lipids and inflammatory response in the same organ. 
Beyond the direct effects of HABs described above, it is unknown how HAB exposure affects other physiological functions, such as reproduction. Relationships between food quality and quantity, energy storage, and reproduction are now well established in $C$. gigas (Soudant et al., 1999; Berthelin et al., 2000; Royer et al., 2008; Rico-Villa et al., 2009). These observations suggest that $\mathrm{HAB}$ exposure, by affecting nutrition-related functions, may impact reproduction processes and gamete output. Indeed, it is well-established that reserve lipids play an important role in gamete production and larval development (Soudant et al., 1996, 1998). Consequently, the effects of harmful algae on digestive-gland lipids, as demonstrated by Haberkorn et al. (in press), may further affect gametogenic processes, reproduction output and larval development.

Most studies concerning the effects of harmful algae on reproductive cycles of bivalves are focusing on embryonic and larval development (Yan et al., 2001 and 2003; Springer et al., 2002; Leverone et al., 2006; Padilla et al., 2006; Shumway et al., 2006). Some studies have observed alterations induced by noxious compounds on quality of gametes produced by oysters (Nice, 2005; Ringwood et al., 2004; Yurchenko et al., 2009), but there are no studies addressing the effects of harmful algae on gametes produced by HAB-exposed bivalve broodstock. Spermatozoa quality, and especially spermatozoa motility, influence successful fertilization in free-spawning invertebrates (Nice, 2005). A positive relationship between ATP content and spermatozoan motility has been reported in carp Cyprinus carpio (Perchec et al., 1995). Other sperm characteristics (viability, acrosomal integrity, mitochondrial membrane potential, and DNA integrity) in relation to fertilizing capacity can be accurately and rapidly measured using flow cytometry coupled with fluorescent markers (Gillan et al., 2005; Cordelli et al., 2005). For example, mitochondrial membrane potential measured with JC-1 was shown to be reasonably predictive of in vitro fertilisation rates (higher in a group with high mitochondrial membrane potential) (Kasai et al., 2002).

The purpose of the present study was to determine the effects of an artificial bloom of the toxin-producing dinoflagellate, A. minutum (strain AM89BM) on nutrition-related processes and reproduction of $C$. gigas; to do so, the digestive gland was assessed for histopathological condition, toxin accumulation, lipid composition, and amylase activity. Further, spermatozoa quality was measured in oysters (C. gigas) after 4 days of exposure to A. minutum or Isochrysis sp. (clone Tahitian T. Iso) as a nutritious, non-toxic control. 


\section{Materials and Methods}

\subsection{Biological material}

\subsubsection{Oysters}

Diploid Pacific oysters, Crassostrea gigas, used in the experiment were obtained from an oyster producer at île de Kerner (Morbihan, France). Mean total oyster fresh weight was 11.9 $\pm 1.2 \mathrm{~g}$ and mean shell length was $62.6 \pm 2.7 \mathrm{~mm}$.

\subsubsection{Algal culture}

Alexandrium minutum (strain AM89BM - isolated in Bay of Morlaix France, in 1995) was grown in 10-liter batch culture using autoclaved seawater filtered through a $1-\mu \mathrm{m}$ filter and supplemented with L1 nutrient enrichment (Guillard and Hargraves, 1993). Cultures were incubated at $16 \pm 1^{\circ} \mathrm{C}$ and $100 \mu \mathrm{mol}$ photon. $\mathrm{m}^{-2} \cdot \mathrm{s}^{-1}$, with a dark:light cycle of $12: 12 \mathrm{~h}$. A. minutum was harvested after 12 days, still in exponential growth phase under our conditions. At this stage, this strain produced $1.3 \pm 0.1$ pg saxitoxin equivalent (STX eq.) per cell (measured by the method of Oshima, 1995).

Isochrysis galbana, clone Tahitian (T.Iso), cultures were obtained from the Argenton hatchery (Ifremer, France). Cultures were produced in 300-liter cylinders containing 1- $\mu \mathrm{m}$ filtered seawater enriched with Conway medium at $24 \pm 1{ }^{\circ} \mathrm{C}$, air- $\mathrm{CO}_{2}(3 \%)$ mix aerated, and with continuous light. T.Iso was harvested in the exponential growth phase (4-5 days) for the feeding experiments.

\subsection{Experimental design of $\boldsymbol{A}$. minutum exposures}

This experiment was performed on mid-June 2008. To proceed, 120 oysters were placed randomly in six 15-liter tanks (20 oysters per tank). Oysters were acclimated for 10 days with a continuous flow of $14 \mathrm{ml} \cdot \mathrm{min}^{-1}$ of seawater (filtered through a $0.5-\mu \mathrm{m}$ filter) with T.Iso at 
$5.10^{5}$ cells. $\mathrm{ml}^{-1}$ at $16 \pm 1{ }^{\circ} \mathrm{C}$. After acclimation, oysters were fed continuously for 4 days at 14 ml.min ${ }^{-1}$ with $5.10^{5}$ cells.ml ${ }^{-1}$ of T.Iso ( 3 control tanks) or with $5.10^{3}$ cells. $\mathrm{ml}^{-1}$ of A. minutum (3 treatment tanks). These two different cell densities were used to provide the same biovolume of microalgae to oysters because the cellular volume of A. minutum is about $100 \mathrm{x}$ higher than that of T.Iso.

\subsection{Oyster sampling}

At the end of the algal exposure, all oysters were sampled and distributed as follows. For each tank (20 oysters), five oysters were used for histological diagnosis, and five oysters were used for individual plasma and hemocyte variable measurements (data not shown) and condition index. Pooled digestive glands from another ten oysters from each tank were used to measure toxins, neutral and polar lipid contents, and amylase activity. Prior to dissection of digestive glands, male oysters ( 8 from the control treatment and 8 from the A. minutum treatment) were selected to assess spermatozoa quality.

\subsection{Histology}

A 4-mm cross-section of each of the five oysters sampled for histology, including digestive gland, gills, mantle, and gonad, was taken. Adductor muscles were dissected separately. Dissected tissues were fixed in Davidson's fixative (Shaw and Battle, 1957) for $48 \mathrm{~h}$. Crosssections and muscles were dehydrated in ascending ethanol solutions, cleared with xylene, and embedded in paraffin wax. Five-micrometer thick sections were cut, mounted on glass slides, and stained with Harris' Hematoxylin-Eosin (Martoja and Martoja-Pierson, 1967). Slides were examined under a light microscope.

\section{Gametogenic stage}

Gametogenic stage was determinated according to the reproductive scale established by Mann (1979).

\section{Pathological conditions: intensity of pathologies}


Gills, gonads, style sac, intestinal groove, intestine, digestive ducts, and digestive tubules were present in all cross-sections and compared between treatments.

After a preliminary diagnosis of all slides (A. minutum exposed and T.Iso-exposed oysters), a list of the most common pathological conditions per organ was established as follows:

- digestive gland (intestinal groove, intestine, digestive ducts and digestive tubules) : i) surrounding hemocytes and ii) hemocytes in diapedesis in the epithelium

- gills: presence of mucus

- muscle: i) myoathrophy, ii) wavy-pattern degeneration and iii) hyaline degeneration

A semi-quantitative scale was defined to classify the intensity of each pathological condition. Each pathological condition was graded as i) absence or very light (stage 0), ii) light-moderate (stage 1), and iii) heavy (stage 2). Based upon this scale, a mean intensity of each pathology was calculated for each specific tissue as follows:

$\sum$ (Stage individual $1+$ Stage individual $2+\ldots+$ Stage individual $\mathrm{n}$ )/ $\mathrm{n}$, (where $\mathrm{n}$ is the number of diagnosed animals per treatment)

\section{Pathological conditions: general status}

To estimate the total pathological status of the digestive gland and the muscle for each microalgal-exposure treatment, mean number of pathologies (simply defined here as presence or absence) was calculated as follow:

Mean number pathologies in digestive gland or in muscle $=\sum$ (number of pathologies individual ${ }_{1}+$ number of pathologies individual $2+$ number of pathologies individual $n$ ) / $n$, (where $n$ is the number of diagnosed animals per treatment)

\subsection{Condition index}


To assess oyster-meat dry weight, soft tissues were removed from shells and placed in a preweighed aluminum cup. Shell and meat were dried for $48 \mathrm{~h}$ at $70^{\circ} \mathrm{C}$ and then weighed. Condition index of each, individual oyster was then calculated as described previously (Lucas and Beninger, 1985), following the formula: ( $g$ dry meat weight / $g$ dry shell weight) $\mathrm{x} 100$.

\subsection{Digestive-gland variables}

Just after dissection, digestive glands were frozen immediately in liquid nitrogen, weighed, pooled ( 1 pool of 10 digestive glands per tank), and stored at $-80^{\circ} \mathrm{C}$ until analysis. Later, pools were ground with a Dangoumeau apparatus in liquid nitrogen and divided for three different analyses.

\subsubsection{Toxin content}

One gram of ground digestive gland (DG) was extracted in $2 \mathrm{ml}$ of $0.1 \mathrm{~N} \mathrm{HCl}(2 \mathrm{v} / \mathrm{w})$ at $4{ }^{\circ} \mathrm{C}$. After centrifugation $\left(3,000 \times \mathrm{g}, 15 \mathrm{~min}, 4^{\circ} \mathrm{C}\right)$, the $\mathrm{pH}$ of each extract was adjusted. If above $3.0, \mathrm{pH}$ was adjusted to 3.0 with $12 \mathrm{~N} \mathrm{HCl}$. After half-dilution, supernatants were ultrafiltered (20 kDa, Sartorius Centrisart) and stored at $4^{\circ} \mathrm{C}$ until analysis. PSTs were analyzed by ion-pairing, high-performance liquid chromatography (IPHPLC) according to the method of Oshima (1995). The molar concentration $\left(\mu \mathrm{mol} . \mathrm{l}^{-1}\right.$ ) was converted into $\mu \mathrm{g}$ STX eq. $100 \mathrm{~g}^{-1}$ of digestive gland using the conversion factors of Oshima (1995). Results were expressed as $\mu \mathrm{g}$ STX eq. $100 \mathrm{~g}^{-1}$ of digestive gland wet weight.

\subsubsection{Lipid-class contents}

Two-hundred and fifty $\mathrm{mg}$ of ground DG was extracted in $6 \mathrm{ml}$ of Folch solution (chloroform:methanol 2:1). Lipid classes were analyzed by high-performance, thin-layer chromatography (HPTLC) on HPTLC glass plates $(1,010 \mathrm{~mm})$ pre-coated with silica gel 60 from Merck (Darmstadt, Germany). 
For neutral lipids, a preliminary run was carried out to remove possible impurities using hexane:diethyl ether $(1: 1)$, and the plate was activated for $30 \mathrm{~min}$ at $110^{\circ} \mathrm{C}$. Lipid samples (4 $\mu 1)$ were spotted on the plates by the CAMAG automatic sampler (CAMAG, Switzerland). The neutral lipids were separated with a solvent system containing hexane:diethyl ether:acetic acid (20:5:0.5).

For polar lipids, a preliminary run was carried out to remove possible impurities using methyl-acetate:iso-propanol:chloroform:methanol: $\mathrm{KCl} 0.25 \%(10: 10: 10: 4: 3.6)$, and the plate was activated for $30 \mathrm{~min}$ at $110^{\circ} \mathrm{C}$. Lipid samples $(6 \mu \mathrm{l})$ were spotted on the plates by the CAMAG automatic sampler. The polar lipids were separated with the above solvent system.

Lipid classes appeared as black spots after dipping plates in a cupric-sulfate, phosphoric-acid solution and heating for $20 \mathrm{~min}$ at $160^{\circ} \mathrm{C}$ (charring). Seven neutral-lipid classes (free fatty acids, sterol esters, glycerid ethers, monoacylglycerol, diacylglycerol, triacylglycerol, sterols) and six polar lipid classes (cardiolipin = bisphosphatidylglycerol, lysophosphatidylcholine, phosphatidylcholine, phosphatidylethanolamine, phosphatidylserine, phosphatidylinositol + ceramide aminoethylphosphonate, that migrate together) were identified based upon authentic standards (Sigma-Aldrich, France) and coloring techniques.

The charred plates were read by scanning at $370 \mathrm{~nm}$, and black spots were quantified using Wincats software (CAMAG, Switzerland). Results were expressed as mg of each identified lipid class per g of digestive gland wet weight.

\subsubsection{Amylase activity}

Two hundred $\mathrm{mg}$ of DG was homogenized in $1 \mathrm{ml}$ of distilled water. Two hundred $\mu 1$ of this solution were added to $10 \mu \mathrm{l}$ of a $0.5 \mathrm{M} \mathrm{CaCl}_{2}$ solution before analysis to assess amylase activity. Amylase activity was then assayed by determination of starch hydrolysis according to the iodine reaction (Samain et al., 1977) modified by Le Moine et al. (1997). One unit of alpha-amylase was defined as the amount of enzyme that degrades $1 \mathrm{mg} \cdot \mathrm{min}^{-1} \mathrm{starch}$ at $45^{\circ} \mathrm{C}$.

To assess specific activity of amylase, total proteins were determined using the BCA Protein Assay (Biorad). For protein extraction, $200 \mu \mathrm{l}$ of the above solution was added to $200 \mu \mathrm{l}$ of a 
$2 \mathrm{~N} \mathrm{NaOH}$ solution. Protein analysis was carried out on $10 \mu \mathrm{l}$ of $1 / 10$ diluted samples according to the manufacturer's description. Briefly, $200 \mu \mathrm{l}$ of dye reagent was added to $10 \mu \mathrm{l}$ of sample and incubated at $37^{\circ} \mathrm{C}$ for 1 hour, and the absorbance was measured at $595 \mathrm{~nm}$. Sample ODs were compared to a standard curve of Bovine Serum Albumin (BSA), and results were expressed as mg protein. $\mathrm{ml}^{-1}$. Results are expressed as amylase activity (in IU) per mg of total protein.

\subsection{Spermatozoa quality}

Oyster gonads were incised, and a sample of gametes was checked under the light microscope to determine the sex of each individual. When identified as male, spermatozoa were sampled, counted (under dark field microscope), and adjusted to $1.10^{7}$ cells per $\mathrm{ml}$ in filtered sterile seawater (FSSW).

\section{Flow cytometric analysis}

Analysis of spermatozoa viability, DNA content, and mitochondrial membrane potential were performed using a FACScalibur flow cytometer (BD Biosciences, San Jose, CA USA) equipped with standard optics and a $488 \mathrm{~nm}$ argon laser.

\section{Assessment of viability}

An aliquot of $100 \mu \mathrm{l}$ of spermatozoa suspension from each selected, individual, male oyster was transferred into a tube containing $900 \mu \mathrm{FSSW}$. Spermatozoa DNA was stained with two fluorescent DNA/RNA specific dyes (1\% final concentration for both), SYBR Green I (Molecular probes, Eugene, Oregon, USA, 1/1000 of the DMSO commercial solution), and propidium iodide (PI, Sigma, St Quentin Fallavier, France, final concentration of $10 \mu \mathrm{g} \cdot \mathrm{ml}^{-1}$ ) in the dark at $18^{\circ} \mathrm{C}$ for 10 minutes before flow-cytometric analysis. PI permeates only spermatozoa that lose membrane integrity and are considered to be dead (necrotic); whereas, SYBR Green I permeates both dead and live cells. SYBR Green and PI fluorescences were measured at 500-530 nm (green) and at 550-600 nm (orange), respectively, by flow cytometry. This method distinguished viable, "dying" (PI partially incorporated) and dead cells. Thus, by counting the cells stained by SYBR Green and cells stained by PI, it was possible to estimate the percentage of dead cells in each sample. 


\section{Estimation of relative DNA content}

On the above stained samples, relative DNA content of spermatozoa was estimated using fluorescence intensity of SYBR Green I in spermatozoa and expressed as arbitrary units (A.U) of green fluorescence.

\section{Assessment of mitochondrial membrane potential}

The mitochondrial membrane potential of oyster spermatozoa was measured using the potential-dependent J-aggregate-forming delocalized lipophilic cation, 5,5',6,6'-tetrachloro1,1',3,3'-tetra-ethylbenzimidazol carbocyanine iodide (JC-1, Molecular probes, Eugene, Oregon, USA). This probe enters selectively into mitochondria and exists as two forms, monomeric or aggregate, depending upon membrane potential (Reers et al. 1991). The JC-1 monomer form predominates in mitochondria with low membrane potential and emits in the green wavelength $(525-530 \mathrm{~nm})$. The JC-1 aggregate form accumulates in mitochondria with high membrane potential and emits in the high orange wavelength $(590 \mathrm{~nm})$. JC-1 forms can change reversibly.

Eight hundred microliters of the spermatozoa suspension (previously adjusted to $1.10^{7}$ ) was transferred into a tube previously load with $190 \mu \mathrm{FSSW}$ and $10 \mu 1 \mathrm{JC}-1$ (0.5 mM). Samples were incubated for $10 \mathrm{~min}$ at room temperature. After incubation, $100 \mu 1$ of JC-1-stained sample was diluted in $900 \mu \mathrm{FSSW}$ and stored on ice prior to flow-cytometric analysis. Fluorescence intensities of JC-1 monomers and aggregates were quantified, respectively, by FL1 and FL2 detectors of the flow cytometer. The JC-1 aggregate/monomer ratio is assumed to be proportional to mitochondrial membrane potential (Reers et al., 1991; Cossarizza et al., 1996). FL1 and FL2 fluorescence intensities are volume-dependent when their ratio is constant at a given membrane potential (Reers et al., 1991).

\section{Motility}

The percentage of motile spermatozoa was assessed using a two-step dilution in a salt spermactivating solution "Moti-gigas" (Brizard et al, 2001) and observed through a dark-field microscope. Percentage of motile spermatozoa was estimated by observations of three optical fields. Results were expressed as mean \pm CI percentage of motile spermatozoa.

\section{ATP content}


For intracellular ATP content, sperm samples $(15 \mu 1)$ were frozen in liquid nitrogen after dilution in "Store-gigas" (135 $\mu 1$, Brizard et al, 2001) according to manufacturer procedures. ATP content was determined by bioluminescence (ATPlite Luminescence Assay System, Perkin - Synergy HT Multi-Mode Microplate Reader, BioTek). Results were expressed as nmol of ATP per $10^{9}$ spermatozoa.

\subsection{Statistical analysis}

Differences between microalgal treatments were analyzed statistically using Student's T-test (after Kolmogorov-Smirnov test to check normal distribution of data) to assess differences linked to treatment for physiological and spermatozoa variables.

Variables expressed as ratio or percentage were transformed as arcsin(squareroot) before statistical analysis, but presented as non transformed data in figures.

Intensity of each pathological condition observed by histology was compared statistically using the Mann-Whitney U-test to assess differences attributable to microalgal exposure. For the sum of binary pathological data (presence/absence), the T-test was used to assess differences attributable to microalgal exposure.

Statistical analyses were performed using Statgraphics Plus statistical software (Manugistics, Inc, Rockville, MD, USA). Results were considered significant when p-value was $<0.05$. 


\section{Results}

\subsection{Histology}

\section{Gametogenic stage}

There were $33 \%$ males and $67 \%$ females in the cohort of oysters fed T.Iso, and $53 \%$ males and $47 \%$ females in oysters exposed to A. minutum. There was no significant difference ( $\mathrm{p}=0.27$; Chi-squared; contingency table) in sex ratio between the A. minutum and T.Iso conditions. All analyzed oysters were ripe (stage 3).

\section{Pathological conditions: intensity of pathologies}

Digestive tubules of all oysters (both microalgal treatments) showed a star-shape in the lumen formed by digestive cells, indicating that the oysters were actively feeding and absorbing. Some intact cells of A. minutum were observed in the intestinal groove and intestine of oysters exposed to this microalgae (cross-sections did not demonstrate the stomach, but did show style sac and intestinal groove). No intact cells of T.Iso were observed in any part of the digestive gland, and no A. minutum cells were observed in digestive ducts and tubules.

Most intense pathological conditions described hereafter were observed in oysters exposed to A. minutum. Presence of pathological conditions in control oysters was occasionally observed but can be considered as pre-existing, background pathologies attributable to unknown environmental irritants in the field.

Pathological conditions observed in the digestive gland consisted most frequently of inflammatory responses characterized by hemocyte aggregations around the intestinal groove and intestine, and to a lesser extent around digestive ducts and tubules (Fig. 1 and 2). Intensities of hemocyte aggregations in the intestinal groove and intestine were significantly higher in oysters exposed to A. minutum than in the controls (Table 1).

Hemocytes in diapedesis (migration of hemocytes through the epithelia) were also observed in the digestive gland (Fig. 1 and 2). Intensities of hemocytes in diapedesis in intestinal groove, intestine, and digestive ducts were significantly higher in oysters exposed to $A$. 
minutum than in control oysters (Table 1). Only one control oyster (of fifteen) had hemocytes in diapedesis in the digestive tubules.

Adductor muscles of some oysters were affected by three types of myopathy as opposed to the normal pattern (Fig. 3 A): myoatrophy (Fig. 3 B), wavy-pattern degeneration (Fig. 3 C) and hyaline degeneration (Fig. 3 D). Myoatrophy was characterized by round muscle fibers surrounded by halos. Wavy-pattern degeneration was characterized by wavy and disorganized muscle fibers. Hyaline degeneration was characterized by a homogenous pink color, hyaline (no organelles are visible) and abnormal round forms of the muscle fibers. Intensities of myoatrophy and hyaline degeneration were significantly higher in oysters exposed to $A$. minutum, as compared to those fed T.Iso (Table 1). Wavy-pattern and hyaline degeneration were not observed in any control oysters.

Although gill tissue structures were not altered, histological observations revealed higher mucus production in A. minutum-exposed oysters (Fig. 4) in relation to controls. Mucus production in gills of $A$. minutum-exposed oysters was significantly more intense than in the control oysters (Table 1).

\section{Pathological conditions: general status}

The total number of pathological conditions observed in the digestive gland was significantly higher $(\mathrm{p}<0.001 ; \mathrm{n}=15 ; \mathrm{T}$-test $)$ in the oysters exposed to A. minutum $(6.2 \pm 0.8)$ in comparison to oysters fed T.Iso $(3.1 \pm 0.7)$. There were also significantly more pathological abnormalities in the muscle $(\mathrm{p}<0.01 ; \mathrm{n}=15 ; \mathrm{T}$-test $)$ in oysters exposed to A. minutum $(1.6 \pm 0.6)$ than in oysters fed T.Iso $(0.4 \pm 0.3)$.

\subsection{Wet weight of digestive gland and condition index}

Condition index did not significantly vary $(\mathrm{p}>0.05, \mathrm{n}=12$, T-test) between oysters exposed to A. minutum or T.Iso, being $6.1 \pm 0.9$ and $5.8 \pm 1.4$, respectively. Body dry weight did not significantly vary ( $\mathrm{p}>0.05, \mathrm{n}=12$, T-test) between oysters exposed to A. minutum or T.Iso, being $0.6 \pm 0.1 \mathrm{~g}$ and $0.5 \pm 0.1 \mathrm{~g}$, respectively. 


\subsection{Toxin content}

PST content in digestive glands of exposed oysters (A. minutum) was $145.5 \pm 3.3 \mu \mathrm{g}$ STX eq. $100 \mathrm{~g}^{-1}$ of digestive gland wet weight. No PSTs were detected in any pool of digestive glands from control oysters (fed T.Iso).

\subsection{Digestive-gland variables}

There was no variation of total neutral lipid contents in digestive glands of oysters regardless of experimental treatment (Fig. 5). Phospholipid contents decreased significantly in digestive glands of oysters exposed to A. minutum in comparison to those fed T.Iso (Fig. 5).

\subsubsection{Neutral lipid contents}

Neutral lipid classes detected in digestive glands were free fatty acids, sterol esters, ether glycerides, sterols, monoacylglycerols, diacylglycerols and triacylglycerols (Fig. 6).

Monoacylglycerol and diacylglycerol contents were significantly lower $(\mathrm{p}=0.009$ and $\mathrm{p}=0.0005$, respectively; T-test) in oysters exposed to A. minutum as compared to those fed T.Iso (Fig. 6).

Contents of sterols and sterol esters were significantly higher $(\mathrm{p}=0.0016$ and $\mathrm{p}=0.0307$, respectively; T-test) in oysters exposed to A. minutum as compared to those fed T.Iso (Fig. 6).

\subsubsection{Polar lipid contents}

Polar lipid classes detected in digestive glands were lysophosphatidylcholine (LPC), phosphatidylcholine (PC), phosphatidylethanolamine (PE), phosphatidylinositol + ceramide aminoethylphosphonate (PI+CAEP), phosphatidylserine (PS) and cardiolipin (CL) (Fig. 7).

CL and PS were significantly higher ( $\mathrm{p}=0.003$ and $\mathrm{p}=0.0002$, respectively; T-test) in oysters exposed to A. minutum as compared to those fed T.Iso (Fig. 7). Exposure to A. minutum resulted in significant decreases in PC, LPC, PE and PI+CAEP $(p=0.0002, p=0.014, p=0.0426$ and $\mathrm{p}=0.0344$, respectively; T-test) in relation to controls (Fig. 7). 


\subsubsection{Amylase-specific activity}

There was no significant variation in digestive-gland wet weight, protein content and amylase-specific activity in digestive gland between different microalgal exposures (Table 2).

\subsection{Spermatozoa variables}

Motility and ATP content of spermatozoa extracted from A. minutum-exposed oysters were significantly lower ( $p=0.0161$ and $p=0.0253$, respectively; T-test) in relation to controls (Fig. $8 \mathrm{~A}$ and $8 \mathrm{~B})$. Three control oysters produced spermatozoa characterized by high motility and high ATP content. No A. minutum-exposed oysters produced spermatozoa with such high motility and ATP.

Sybr green I fluorescence intensity (related to DNA content and/or conformation) of stained, viable spermatozoa was significantly lower and much more variable in oysters exposed to $A$. minutum than in those fed T.Iso $(\mathrm{p}=0.031$ and $\mathrm{p}=0.048$, U-test and Kolmogorov-Smirnov test, respectively, Fig. 8C). Side Scatter of viable spermatozoa (data not shown) of A. minutumexposed oysters was significantly higher in relation to controls $(\mathrm{p}=0.014$, T-test). The mean percentage of dead spermatozoa was significantly lower ( $\mathrm{p}=0.0039$, T-test, Fig. $8 \mathrm{D})$ in oysters exposed to A. minutum in relation to those fed T.Iso.

The mitochondrial membrane potential of spermatozoa was measured using the lipophilic cation JC-1. Fluorescence intensities of JC-1 monomers and aggregates were quantified respectively by FL1 and FL2 detectors of the flow cytometer. The JC-1 aggregate/monomer ratio (an estimation of mitochondrial membrane potential) was not significantly different between experimental treatments (Fig. 8E). JC-1 monomer fluorescence intensity (an estimation of total JC-1 incorporation), however, was significantly higher in spermatozoa of oysters exposed to A. minutum than to those of oysters fed T.Iso ( $\mathrm{p}=0.0007$, T-test, Fig. 8F). Similarly, JC-1 aggregate fluorescence intensity (data not shown) was significantly higher in spermatozoa of oysters exposed to A. minutum compared to controls. 


\section{Discussion}

Comparison of A. minutum-exposed oysters with controls feeding on a microalga known to be nutritious, T.Iso, was contingent upon confirmation that oysters were actively feeding on and ingesting both microalgae. All oysters (of both diets) observed by histology were actively digesting microalgae ingested, based upon the star-shape of lumena in digestive tubules (this reveals that tubules are actively absorbing). This indicates that the oysters can at least partially digest A. minutum cells, despite potential toxicity. Nevertheless, presence of both intact cells and temporary cysts in the digestive system (intestine groove and intestine) and feces (data not shown) of oysters exposed to A. minutum suggests that the oysters were unable to completely digest all ingested cells of this species. Presence of intact, harmful-algal cells in the digestive system of exposed bivalves has already been observed by Galimany et al. (2008a and c). Hégaret et al. (2007, 2008a) reported presence of intact Alexandrium cells and temporary cysts in bivalve feces. Persson et al. (2006) also observed temporary cysts of $A$. fundyense in feces of oysters feeding on vegetative cells. A. minutum may prevent digestion by forming cysts.

In a previous study, paralysis of adductor muscles of Crassostrea virginica was one visible effect observed upon Alexandrium fundyense exposure (Hégaret et al., 2007). Recently, Tran et al. (2010) reported behavior changes in C. gigas upon exposure to A. minutum, e.g., increases in valve-opening duration and number of abnormal micro-closures. The latter is possibly related to dysfunction of adductor muscle. Moreover, although mechanisms remained unclear, adductor muscles of Ruditapes philippinarum were shown to be altered after exposure to Prorocentrum minimum (Hégaret et al., 2009). In accordance with the above-cited studies, adductor muscles of A. minutum-exposed oysters in the present study were intensely affected by myopathy: myoatrophy, hyaline degeneration and wavy-pattern degeneration. Such changes of muscle tissue structure may be associated with the muscle paralysis observed during Alexandrium exposure in C. virginica and Mytilus edulis (Hégaret et al., 2007; Galimany et al., 2008a). Observed myodegeneration may partially explain the modifications in valve activity of oysters exposed to A. minutum (Tran et al., 2010). Such modifications of muscle structure and activity can possibly affect oyster respiration and nutrition processes, as adductor muscle contraction contributes to maintenance of optimal amplitude of valve opening (Frank et al., 2007). The gill, however, remains the most important organ regarding respiration and feeding, and thus, this organ is expected to be the 
first in contact with toxic or non-toxic phytoplankton cells. Histological observations revealed that gills were affected by A. minutum exposure. Significantly-increased mucus production was observed in A. minutum-exposed oysters in relation to controls. Shumway and Cucci (1987) showed that some bivalves (Mytilus edulis, Placopecten magellanicus, and Geukensia demissa) increased mucus production after exposure to Protogonyaulax tamarensis (= Alexandrium tamarense), probably to avoid consumption of toxic cells. Mucus associated with gills also contains powerful lytic enzymes that act against a variety of stressors and play an important role in defense (Fisher, 1992; Brun et al., 2000).

This reaction to harmful and/or toxic microalgal exposure was also noted in finfish. Excess mucus production in gills of brown trout (Salmo trutta) exposed to a cyanobacterial (bluegreen algal) bloom was suggested to be related to acute irritation (high $\mathrm{pH}$, physical irritation caused by high bloom density, a direct, toxic effect of toxins, or a combination of all of these factors) (Rodger et al., 1994). Exposure to Cochlodinium polykrikoides also resulted in increases of mucus production by gills in several fish species (Kim et al., 2000). It is thought that increased mucus production by oyster gills probably reflects tissue irritation and/or defense reaction to A. minutum cells and/or extra-cellular, bioactive compounds.

In the present study, inflammatory responses, in the form of aggregations of hemocytes and massive migration of hemocytes through the epithelia by diapedesis, were observed in the digestive gland and were especially prominent in oysters exposed to A. minutum. The digestive gland, intestinal groove, and intestine were the tissues most-affected by these inflammatory responses. Galimany et al. (2008a, b, c) described similar, inflammatory responses (infiltration and diapedesis of hemocytes) in blue mussels (Mytilus edulis) exposed to Alexandrium fundyense, Prorocentrum minimum or Karlodinium veneficum. Hégaret et al. (2009) also observed infiltration of hemocytes into the intestine and gonad follicles of Ruditapes philippinarum exposed to P. minimum. Estrada et al. (2007) observed aggregation of hemocytes in the digestive gland, mantle, and gills of the scallop, Nodipecten subnodosus, exposed to the toxigenic dinoflagellate Gymnodinium catenatum. Smolowitz and Shumway (1997) described inflammatory responses in different organs of several bivalve species (such as Argopecten irradians, Crassostrea virginica and Ostrea edulis) exposed to Gyrodinium aureolum (Karenia mikimotoï). 
Three hypotheses can be formulated to explain such a response. The first involves a reaction directly against toxic microalgal presence within the lumina of the alimentary canal. Galimany and co-workers (2008b) suggested that massive migration of hemocytes into the stomach and intestine was a defense response of mussels to protect tissues from exposure to $P$. minimum. Encapsulation of $P$. minimum cells by Ruditapes philippinarum hemocytes has been also suggested by Hégaret et al. (2009). Similarly, aggregates of Mercenaria mercenaria hemocytes surrounding P. minimum cells when exposed in vitro have been observed by Hégaret (2007) and Hégaret et al. (2008b). Results of the present and previous studies support the hypothesis that hemocytes migrate into the lumina of digestive organs to remove $A$. minutum cells and/or to protect tissues from toxicity. This reaction is clearly a non-specific immune response as it has been reported in different harmful algae/bivalve interactions.

In a second hypothesis, presence of bacteria in the lumina of the digestive system can also explain such inflammatory responses; hemocytes may possibly be responding to neutralize opportunistic bacterial infections advanced by exposure to toxic algae. Hégaret et al. (2009) suggested that presence of large amounts of bacteria and hemocytes in the intestinal lumena of $R$. philippinarum reflected a failed attempt of the immune system to suppress opportunistic bacterial pathogens. Furthermore, Galimany et al. (2008b) observed that hemocytes engulfed bacteria by phagocytosis in the alimentary canal lumina of mussels exposed to P. minimum.

As a third hypothesis, hemocyte migration by diapedesis across intestine epithelia can be considered as a detoxification pathway (Galimany et al., 2008a). Indeed, hemocytes are suspected to carry toxins bound to lipofuchsin granules (in lysosomes), toward the alimentary canal for elimination in feces.

There was no apparent link between histological observations (massive presence of hemocytes in digestive tissues) and cell density of hemocytes circulating in the open vascular system (data not shown). Indeed, there was no significant variation of hemocyte and plasma variables according to microalgal exposure (data not shown). As hemocytes are thought to migrate from the circulatory system (hemolymph) to tissues, it is expected that the concentration of circulating hemocytes in hemolymph would decrease upon A. minutum exposure. Absence of such a decrease in circulating hemocytes can be interpreted as an increase in hemocyte production in response to A. minutum exposure compensating hemocyte migration from hemolymph toward tissues. The low percentage of dead hemocytes in 
hemolymph for both microalgal treatments was confirmed by the absence of necrotic and apoptotic hemocytes observed by histology.

From the histological observations in the digestive gland, it can be expected that digestion and assimilation of nutrients are likely impaired upon A. minutum exposure. This histological approach was further combined with a biochemical approach to determine if changes in energy-reserve contents, enzymatic activities, or structural compounds are concomitantly observed with the tissue alterations described above.

Both structural and reserve lipids were affected upon A. minutum exposure. Phospholipids (structural lipids), however, were the most drastically impacted by A. minutum exposure; the total polar lipid content decreased by $24 \%$ in digestive glands. No obvious relationship between inflammatory responses and phospholipid (PL) changes in digestive glands can be established so far. Abundance of hemocytes (mainly containing of PLs, Delaporte et al., 2003) in the digestive gland was expected to increase phospholipid content. But, the contrary was observed. Decrease of total polar lipids was mainly attributable to a two-fold decrease in PC. PC is generally considered as the "hub" in PL synthesis/remodeling and has the highest turnover. PE, PI+CAEP and LPC also contributed to the PL decrease, but at a lesser extent. On the contrary, CL and PS, two minor PLs, increased drastically upon A. minutum exposure, up $38 \%$ and $134 \%$, respectively. Such drastic changes in PL composition in the digestive gland are surprising, as PL composition is described as very stable even following marked dietary modifications (Soudant et al., 1999). Similarly, PLs showed only small variations in the digestive gland of Pecten maximus during an annual field survey, independently of food availability (Pazos et al., 2003).

Decrease in PL contents was unlikely to have resulted from cell lysis, as free fatty acid (FFA) content was not affected by A. minutum exposure. Presence of high FFA content can generally be interpreted as representing the products of cell degradation (Chu et al., 2003). Moreover, histological observations do not reveal any necrosis in digestive glands.

Coincident with the PL decrease, MAG and DAG also significantly decreased upon $A$. minutum exposure. These compounds are generally absent in gonad and muscle, and only transiently observed in digestive glands of oysters (Soudant et al., 1999). MAG and DAG are thought to be intermediate products in lipid synthesis (Larsson et al., 2006). Decrease in PC, 
the most drastically affected PL by A. minutum exposure, may thus reflect a decrease in PL synthesis as it is coincident with DAG and MAG decreases in neutral lipids. MAG and DAG are precursors in the synthesis of several lipids, including reserve (triacylglycerol) and structural lipids (PC, PE, PI and PS) (Larsson et al., 2006). The turn-over of PLs is likely a relatively-rapid phenomenon in bivalves, in light of rapid adaptation of cell membranes during temperature changes (Farrias et al., 2003). Moreover, PLs show considerably less seasonal variation than neutral lipids (Pazos et al., 1996), suggesting that they are constantly synthesized and renewed. Such inhibition was observed previously in $C$. virginica exposed to PCB. Authors suggested that the observed decrease of PLs was a result of synthesis inhibition (Chu et al., 2003). Absence of decrease in TAG and EGLY contents (these lipids can be metabolized to produce MAG and DAG) suggest that oysters do not use reserve lipids to compensate for reductions in MAG and DAG, synthesis, precursors of PLs including PC, PE, PI and PS. Increases in PS and CL, when other PLs decreased, may reflect synthesis by an alternative pathway involving phosphatidic acid that does not require DAG as a precursor. To summarize, decrease in the main PL classes appeared to be related to a reduction of MAG and DAG synthesis. This reduction is possibly attributable to shortage of precursors resulting from digestion and assimilation dysfunctions, as histological observations showed major changes in tissue structure of the digestive gland upon A. minutum exposure.

Changes in PL composition may also reflect some changes in cell types or in organelles within cells. Indeed, PL class composition is generally found to be specific to organ tissue, cell type, or subcellular compartment (Soudant et al., 1999). Change in cell-type composition is a general phenomenon that can take place in the digestive gland epithelia of stressed mollusks as underscored by Zaldibar et al. (2008). A recent study (Zaldibar et al., 2007) demonstrated that exposure of winkles (Littorina littorea) to cadmium resulted in changes in the composition of the epithelia of the digestive gland (digestive ducts and tubules). These changes were characterized by a loss of digestive cells (minus 13.2\%) and an increase of volume of both digestive and basophilic cells (plus 13.5\% and 200\%, respectively). In this study (Zaldibar et al,. 2007), cell changes were relatively fast, as 20 days of cadmium exposure provoked changes, but cells returned to normal values after a 10-day depuration. Such changes in digestive and basophilic cells were not detected in our study, possibly because of the relatively short time of exposure to A. minutum. Although visible changes in the cells were not detectable by histology, some intra-cellular changes may have occurred causing the observed modification in PL-class composition. 
Finally, lipid peroxidation could also be responsible for the PL decrease, as lipid peroxidation resulted in degradation of polyunsaturated fatty-acid composed molecules. Unfortunately, measurement of peroxidation processes could not be conducted in this experiment.

Decrease in PLs was concomitant with increase in sterol in the digestive gland. The synthesis of sterols takes a different pathway than PLs. This confirms that A. minutum exposure may specifically affect PL synthesis through the MAG and DAG pathway. The observed increase in sterols may somehow correspond with a compensatory response to the decrease of PLs in the digestive gland.

No variations were observed in the digestive gland wet weight, protein content, and amylase activity, suggesting that digestive-gland functions were only partially affected by A. minutum exposure.

Unlike the study by Hégaret et al. (2009) wherein ova degeneration was observed in Ruditapes philippinarum exposed to Prorocentrum minimum, the present study did not reveal such pathology in female gonads. Despite the fact that no pathological conditions or tissue alterations were observed in male and female oyster gonads, spermatozoa (obtained by stripping) were affected by A. minutum exposure.

Spermatozoa of A. minutum-exposed oysters showed low motility and low ATP content as compared to controls. None of the sampled oysters exposed to A. minutum produced spermatozoa with high motility and ATP content as seen in the control oysters, where three oysters of eight contained more than $100 \mathrm{nmol}$ of ATP per $10^{9}$ spermatozoa. Reduced motility resulted likely in the absence of increased ATP content, as ATP has been demonstrated to be essential for sperm motility, and decreased ATP equates with decreased sperm movement (Rurangwa et al., 2002).

Energy released by electron flow of the respiratory chain is used to pump protons across the mitochondrial inner-membrane into the inter-membrane space and generates an electrochemical gradient to drive the synthesis of ATP. The mitochondrial membrane potential resulting from this gradient is, therefore, a sensitive indicator of the energy status of the mitochondria of the cell. In the present study, this was measured using the JC-1 probe. The ratio JC-1 aggregate/monomer fluorescences (proportional to mitochondrial membrane 
potential) was similar in spermatozoa of control and A. minutum-exposed oysters. This suggests that the measured reduction in ATP content within spermatozoa did not result from an impairment of the respiratory chain function and/or of oxidative phosphorylation. Thus, the mechanisms by which A. minutum exposure affected ATP production by mitochondria remain yet to be elucidated.

Moreover, JC-1 monomer fluorescence intensity increased drastically in spermatozoa of $A$. minutum exposed oysters. Reers et al. (1991) stated that fluorescence of the JC-1 monomer can increase upon volume increase of mitochondrial at a constant membrane potential. Mancini et al (1997) used this variable to monitor change in mitochondrial mass. Thus, increase in incorporated JC-1 may reflect an increase in mitochondria volume, but unlikely an increase in mass, as oyster spermatozoa are believed to contain four mitochondria (Dong et al., 2005). This interpretation is supported by increases of FSC and SCC, assumed to be proportional to size and complexity respectively, in spermatozoa of A. minutum-exposed oysters.

Relative DNA content of spermatozoa was also estimated using fluorescence of SYBR Green I, a permeant DNA dye. SYBR Green I fluorescence (expressed in A.U.) was significantly reduced and more variable (as estimated by higher $\mathrm{CI}$ ) in spermatozoa of A. minutum-exposed oysters than in control oysters. It is speculated that these changes may reflect a reduction in DNA content related to chromosome anomalies in the form of missing chromosomes or deletions.

Mortality measured in oyster spermatozoa of the present experiment was in the range found for spermatozoa of other biological models, including vertebrates (Collodel and Moretti, 2008). More surprising was the lower percentage of dead spermatozoa observed in $A$. minutum-exposed oysters in relation to controls. Although apoptosis was not formally measured here, we consider measured cell death/necrosis as the end point of apoptosis. Apoptosis is a well known way to eliminate unwanted genetic material (Singh et al., 2003). ATP synthesized by $\mathrm{F}_{0}-\mathrm{F}_{1}$-ATPase is crucial for the primary pathways of testicular-cell apoptosis (Erkkila et al. 2006). These authors demonstrated that inhibitors of the mitochondrial respiratory chain and oxidative phosphorylation, exposure to anoxia, and inhibition of $\mathrm{F}_{0}-\mathrm{F}_{1}$-ATPase, reduced ATP concentration and resulted thus in anti-apoptotic effect on human germ cells (Erkkila et al. 2006). 
As mentioned above, we observed a reduced concentration of ATP within spermatozoa of $A$. minutum-exposed oysters. As mitochondrial membrane potential (JC-1 aggregate/monomer ratio) remained stable between treatments, the reduction in ATP content can not result from the inhibition of the mitochondrial respiratory chain or oxidative phosphorylation. We thus speculate that the observed ATP depletion resulted from a specific inhibition of $\mathrm{F}_{0}-\mathrm{F}_{1}-\mathrm{ATPase}$ by A. minutum exposure that prevented apoptosis and cell death in oyster spermatozoa as reported for human germ cells (Erkkila et al. 2006).

Alterations in gamete quality in oysters exposed to chemical pollutants were also characterized by the absence of spermatozoa motility (Nice, 2005), decrease in fertilization rate, and damage during embryonic development (Ringwood et al., 2004).

Reduced energy status and motility of spermatozoa associated to morphological changes at cellular and sub-cellular levels upon A. minutum exposure can be expected to have consequences to spermatozoa fertility and reproduction success. In future studies, it would be interesting to further explore subsequent impacts on larval development and spat recruitment. Direct impact on bivalve recruitment has already been observed in Argopecten irradians concentricus during Ptychodiscus brevis (Karenia brevis) bloom in North Carolina (Summerson and Peterson, 1990).

\section{Conclusion}

Exposure to A. minutum impacted several organs and functions in $C$. gigas: gills, muscle, digestive gland, and gametes (spermatozoa). This is the first study showing that HAB exposure can affect mollusc lipid composition and metabolism. Changes in phospholipid classes in the oysters digestive gland upon A. minutum exposure are likely to reflect a perturbation of PL synthesis. Observed modifications of lipids, especially PLs, are more likely to result from A. minutum toxicity (possibly because of PSTs but not only), rather than from poor nutritional quality of this alga. For example, Fernandez-Reiriz et al (2008) demonstrated that mussels, M. chilensis, feeding on A. catenella were able to develop mechanisms which allowed exploitation of the toxic microalgae as a food source (proteins, carbohydrates and lipids). To further confirm such toxic effects upon digestive-gland lipid composition, comparison of effect of PST and non-PST producing Alexandrium species are needed. 
Exposure of oysters to A. minutum also resulted in activation of defense mechanisms, as shown by excess mucus production in gills and acute inflammatory responses in the digestive gland. As a link between inflammatory response and lipid peroxidation is well known in vertebrates, it appears important to further study this relationship in invertebrate models.

Despite the expectation that spermatozoa never experience direct contact with A. minutum cells, these cells also were affected by A. minutum exposure of the adult oyster. We can hypothesize that spermatozoa were mostly affected by the release of toxins upon A. minutum digestion.

The effects of harmful microalgae on bivalve reproduction can be a considerable impediment for aquaculture and natural populations. The present study is the first to demonstrate that toxic microalgae can affect "quality" of gametes issued from HAB exposed broodstock. It appears important to further evaluate the consequences, in terms of fertility, embryo and larvae output upon HAB exposure of oyster broodstock.

\section{Acknowledgments}

We thank Patrick Lassus, Isabelle Queau, Luc Lebrun, René Robert, Jean Yves Quillay, Aimé Langlade, Edouard Bédier, Claudie Quere, Véronique Savar, Aurélie Lelong, Audrey Bruneau and Jérémy Dénès for their help conducting the experiments and their technical assistance. Sincere thanks are due to Gary H. Wikfors for English corrections. This study was carried out with the financial support of the National Research Agency (ANR), "MODECOPHY" project 06SEST23 (2006-2009) and of the Brittany Region, "EPHYTOX” project (2006-2009). 


\section{References}

Bardouil, M., Bohec, M., Cormerais, M., Bougrier, S., Lassus, P., 1993. Experimental study of the effects of a toxic microalgal diet on feeding of the oyster Crassostrea gigas Thunberg. J. Shellfish Res. 12, 417-422.

Berthelin, C., Kellner, K., Mathieu, M., 2000. Storage metabolism in the Pacific oyster (Crassostrea gigas) in relation to summer mortalities and reproductive cycle (West Coast of France) Comp. Biochem. Physiol. B, Biochem. Mol. Biol. 125, 359-369.

Bricelj, V.M., Shumway, S.E., 1998. Paralytic shellfish toxins in bivalve molluscs: occurrence, transfer kinetics, and biotransformation. Res. Fish. Sci. 6, 315-383.

Brizard, R., Bernanrdi, M., Boudry, P., Haffray, P., Labbe, C., Maisse, G., Maurouard, E., Robert, R., Roger, J.L., 2004. Projet Cryoyster : Optimisation, standardisation et validation de la congélation de la laitance d'huître creuse Crassostrea gigas à des fins de conservation et de diffusion génétique. Rapport final OFIMER (03/5 210 093), 36pp.

Brun, N.T., Ross, N.W., Boghen, A.D., 2000. Changes in electrophoretic profiles of gill mucus proteases of the eastern oyster Crassostrea virginica in response to infection by the turbellarian Urastoma cyprine. J. Invertebr. Pathol. 75, 163-170.

Chu, F.L.E., Soudant, P., Hale, R.C., 2003. Relationship between PCB accumulation and reproductive output in conditioned oysters Crassostrea virginica fed a contaminated algal diet. Aquat. Toxicol. 65, 293-307.

Collodel, G., Moretti, E., 2008. Morphology and Meiotic Segregation in Spermatozoa From Men of Proven Fertility. J. Androl. 29, 106-114.

Cossarizza, A., Ceccarelli, D., Masini, A., 1996.Functional Heterogeneity of an Isolated Mitochondrial Population Revealed by Cytofluorometric Analysis at the Single Organelle Level. Exp. Cell Res. 222, 84-94.

Delaporte, M., Soudant, P., Moal, J., Lambert, C., Quere, C., Miner, P., Choquet, G., Paillard, C., Samain, J.F., 2003. Effect of a mono-specific algal diet on immune functions in two bivalve species - Crassostrea gigas and Ruditapes philippinarum. J. Exp. Biol. 206, 3053-3064.

Dong, Q., Huanga, C., Tierscha, T.R., 2005. Spermatozoal ultrastructure of diploid and tetraploid Pacific oysters. Aquaculture 249, 487- 496.

Erkkila, K., Kyttanen, S., Wikstrom, M., Taari, K., Sinha Hikim, A.P., Swerdloff, R.S., Dunkel1, L., 2006. Regulation of human male germ cell death by modulators of ATP production. Am. J. Physiol. Endocrinol. Metab. 290, E1145-E1154.

Estrada, N., de Jesus Romero, M., Campa-Cordova, A., Luna, A., Ascencio, F., 2007. Effects of the toxic dinoflagellate, Gymnodinium catenatum on hydrolytic and antioxidant enzymes, in tissues of the giant lions-paw scallop Nodipecten subnodosus. Comp. Biochem. Physiol. C Pharmacol. Toxicol. Endocrinol. 146, 502-510.

Fantone, J.C., Ward, P.A., 1982. Role of oxygen-derived free radicals and metabolites in leukocyte-dependent inflammatory reactions. Am. J Pathol. 107, 395-418.

Farias, A., Bell, J.G., Uriarte, I., Sargent, J.R., 2003. Polyunsaturated fatty acids in total lipid and phospholipids of Chilean scallop Argopecten purpuratus (L.) larvae: effects of diet and temperature. Aquaculture 228, 289-305.

Fernández-Reiriz, M.J., Navarro, J.M., Contreras, A.M., Labarta, U., 2008. Trophic interactions between the toxic dinoflagellate Alexandrium catenella and Mytilus chilensis: Feeding and digestive behaviour to long-term exposure. Aquat. Toxicol. 87, 
245-251.

Fisher, W.S., 1992. Occurrence of agglutinins in the pallial cavity mucus of oysters. J. Exp. Mar. Biol. Ecol. 162, 1-13.

Frank, D.M., Hamilton, J.F., Ward, J.E., Shumway, S.E., 2007. A fiber optic sensor for high resolution measurement and continuous monitoring of valve gape in bivalve molluscs. J. Shellfish Res. 26, 575-580.

Galimany, E., Sunila, I., Hégaret, H., Ramón, M., Wikfors, G.H., 2008a. Experimental exposure of the blue mussel (Mytilus edulis, L.) to the toxic dinoflagellate Alexandrium fundyense: Histopathology, immune responses, and recovery. Harmful Algae 7, 702-711.

Galimany, E., Sunila, I., Hégaret, H., Ramón, M., Wikfors, G.H., 2008b. Pathology and immune response of the blue mussel (Mytilus edulis L.) after an exposure to the harmful dinoflagellate Prorocentrum minimum. Harmful Algae 7, 630-638.

Galimany, E., Place, A.R., Ramon, M., Jutson, M., Pipe, R.K., 2008c. The effects of feeding Karlodinium veneficum (PLY \# 103; Gymnodinium veneficum Ballantine) to the blue mussel Mytilus edulis. Harmful Algae 7, 91-98.

Grizel, H., Auffret, M. 2003.An atlas of histology and cytology of marine bivalve molluscs. Editions Quae. 201 p.

Guillard, R.R.L., Hargraves, P.E., 1993. Stichochrysis immobilis is a diatom, not a chrysophyte. Phycologia 32, 234-236.

Haberkorn, H., Lambert, C., Le Goïc, N., Guéguen, M., Moal, J., Palacios, E., Lassus, P., Soudant, P., in press. Effects of Alexandrium minutum exposure on physiological and hematological variables of diploid and triploid oysters, Crassostrea gigas. Aquat. Toxicol.

Hégaret, H., 2007. Impacts of Harmful Algal Blooms on Physiological and Cellular Processes of Bivalve Molluscs. Thesis. Ecole Nationale Supérieure Agronomique de Rennes.

Hégaret, H., Wikfors, G., Soudant, P., Lambert, C., Shumway, S., Bérard, J., Lassus, P., 2007. Toxic dinoflagellates (Alexandrium fundyense and A. catenella) have minimal apparent effects on oyster hemocytes. Mar. Biol. 152, 441-447.

Hégaret, H., Shumway, S.E., Wikfors, G.H., Pate, S., Burkholder, J.M., 2008a. Potential transport of harmful algae via relocation of bivalve mollusks. Mar. Ecol. Prog. Ser. 361, 169-179.

Hégaret, H., Wikfors, G.H., Shumway, S.E., 2008b. In vitro interactions between several species of harmful algae and hemocytes of bivalve molluscs. Proceedings of the 12 th International Conference on Harmful Algae, Copenhagen, Denmark.

Hégaret, H., da Silva, P., Sunila, I., Dixon, M.S., Alix, J., Shumway, S.E., Wikfors, G.H., Soudant, P., 2009. Perkinsosis in the Manila clam Ruditapes philippinarum affects responses to the harmful-alga, Prorocentrum minimum. J. Exp. Mar. Biol. Ecol. 371, $112-120$.

Hoagland, P., Anderson, D.M., Kaoru, Y., White, A.W., 2002. The Economic Effects of Harmful Algal Blooms in the United States: Estimates, Assessment Issues, and Information Needs. Estuaries 25, 819-837.

Hoagland, P., Scatasta, S., 2006. The economic effects of harmful algal blooms. In: Graneli, E., Turner, J., (Eds.) Ecology of Harmful Algae. Ecology Studies Series. SpringerVerlag, Dordrecht, The Netherlands, pp. 391-402.

Ignatiades, L., Gotsis-Skretas, O., Metaxatos, A., 2007. Field and culture studies on the ecophysiology of the toxic dinoflagellate Alexandrium minutum (Halim) present in Greek coastal waters. Harmful Algae 6, 153-165.

Kim, C.S., Lee, S.G., Kim, H.G., 2000. Biochemical responses of fish exposed to a harmful dinoflagellate Cochlodinium polykrikoides. J. Exp. Mar. Biol. Ecol. 254, 131-141. 
Kim, C.-J., Kim, C.-H., Sako, Y., 2005. Development of Molecular Identification Method for Genus Alexandrium (Dinophyceae) Using Whole-Cell FISH. Mar. Biotechnol. 7, 215222.

Landsberg, J.H., 2002. The Effects of Harmful Algal Blooms on Aquatic Organisms. Fish. Sci. 10, 113-390.

Larsson, K., Quinn, P., Sato, K., Tiberg, F., 2006. Lipids: structure, physical properties and functionality. The Oily Press. 19, pp280.

Lassus, P., Bardouil, M., Beliaeff, B., Masselin, P., Naviner, M., Truquet, P., 1999. Effect of a continuous supply of the toxic dinoflagellate Alexandrium minutum Halim on the feeding behavior of the Pacific oyster (Crassostrea gigas Thunberg). J. Shellfish Res. $18,211-216$.

Le Moine, S., Sellos, D., Moal, J., Daniel, J.Y., San Juan, S.F., Samain, J.F., Van Wormhoudt, A., 1997. Amylase on Pecten maximus (mollusca, bivalves): protein and cdna characterization; quantification of the expression in the digestive gland. Mol. Marine Biol. Biotechnol. 6, 228-237.

Leverone, J.R., Blake, N.J., Pierce, R.H., Shumway, S.E., 2006. Effects of the dinoflagellate Karenia brevis on larval development in three species of bivalve mollusc from Florida. Toxincon 48, 75-84.

Li, S.C., Wang, W.X., Hsieh, D., 2001. Feeding and absorption of the toxic dinoflagellate Alexandrium tamarense by two marine bivalves from the South China Sea. Mar. Biol. 139, 617-624.

Li, S.C., Wang, W.X., Hsieh, D.P.H., 2002. Effects of toxic dinoflagellate Alexandrium tamarense on the energy budgets and growth of two marine bivalves. Mar. Environ. Res. 53, 145-160.

Lilly, E.L., Halanych, K.M., Anderson, D.M., 2005. Phylogeny, biogeography, and species boundaries within the Alexandrium minutum group. Harmful Algae 4, 1004-1020.

Lucas, A., Beninger, P.G., 1985. The use of physiological condition indices in marine bivalve aquaculture. Aquaculture 44, 187-200.

Mancini, M., Anderson, B.O., Caldwell, E., Sedghinasab, M., Paty, P.B., Hockenbery, D.M., 1997. Mitochondrial Proliferation and Paradoxical Membrane Depolarization during Terminal Differentiation and Apoptosis in a Human Colon Carcinoma Cell Line. J. Cell Biol. 138, 449-469.

Mann, R., 1979. Some biochemical and physiological aspects of growth and gametogenesis in Crassostrea gigas and Ostrea edulis grown at sustained elevated temperatures. J. Mar. Biolog. Assoc. U.K. 59, 95-110.

Martoja, R., Martoja-Pierson, M., Grassé, P.P., 1967. Initiation aux techniques de l'histologie animale. Paris, Masson. pp. 345.

Narahashi, T., 1988. Mechanism of tetrodotoxin and saxitoxin action. In: Handbook of Natural Toxins. Marine Toxins and Venoms, (Tiu, A.T., Ed.) New York: Marcel Dekker Inc. 3, 185-210.

Navarro, J.M., Contreras, A.M., Chaparro, O.R., 2008. Short-term feeding response of the mussel Mytilus chilensis exposed to diets containing the toxic dinoflagellate Alexandrium catenella. Rev. Chil. Hist. Nat. 81, 41-49.

Nice, H.E., 2005. Sperm motility in the Pacific oyster (Crassostrea gigas) is affected by nonylphenol. Mar. Pollut. Bull. 50, 1668-1674.

Oshima, Y., Sugino, K., Itakura, H., Hirota, M., Yasumoto, T., 1990. Comparative studies on paralytic shellfish toxin profile of dinoflagellates and bivalves. In: Toxic Marine Phytoplankton, (Granéli, E., Sundström, B., Edler, L., Anderson, D.M., Eds.) New York: Elsevier Science Publishers, pp. 391-396.

Oshima, Y., 1995. Postcolumn derivatization liquid chromatographic method for paralytic 
shellfish toxins. J AOAC Int. 78, 528-532.

Padilla, D.K., Doall, M.H., Gobler, C.J., Hartson, A., O’Boyle, K., 2006. Brown tide alga, Aureococcus anophagefferens, can affect growth but not survivorship of Mercenaria mercenaria larvae. Harmful Algae 5, 736-748.

Pazos, A.J., Ruiz, C., Garcia-Martin, O., Abad, M., Sanchez, J.L., 1996. Seasonal variations of the lipid content and fatty acid composition of Crassostrea gigas cultured in El Grove, Galicia, N.W. Spain. Comp. Biochem. Physiol. B, Biochem. Mol. Biol. 114, 171-179.

Pazos, A.J., Sánchez, J.L., Román, G., Pérez-Parallé, M.L., Abad, M., 2003. Seasonal changes in lipid classes and fatty acid composition in the digestive gland of Pecten maximus.

Comp. Biochem. Physiol. B, Biochem. Mol. Biol. 134, 367-380.

Perchec, G., Jeulin, C., Cosson, J., André, F., Billard, R., 1995. Relationship between sperm ATP content and motility of carp spermatozoa. J. Cell Sci. 108, 747-753.

Persson, A., Smith, B.C., Wikfors, G.H., Quilliam, M. 2006. Grazing on toxic Alexandrium fundyense resting cysts and vegetative cells by the eastern oyster (Crassostrea virginica). Harmful Algae 5, 678-684.

Ranston, E.R., Webber, D.F., Larsen, J., 2007. The first description of the potentially toxic dinoflagellate, Alexandrium minutum in Hunts Bay, Kingston Harbour, Jamaica. Harmful Algae 6, 29-47.

Reers, M., Smith, T.W., Chen, L.B., 1991. J-aggregate formation of a carbocyanine as a quantitative fluorescent indicator of membrane potential. Biochemistry 30, 44804486.

Rico-Villa, B., Pouvreau, S., Robert, R., 2009. Influence of food density and temperature on ingestion, growth and settlement of Pacific oyster larvae, Crassostrea gigas. Aquaculture 287, 395-401.

Ringwood, A.H., Hoguet, J., Keppler, C., Gielazyn, M., 2004. Linkages between cellular biomarker responses and reproductive success in oysters--Crassostrea virginica. Mar. Environ. Res. 58, 151-155.

Rodger, H.D., Turnbull, T., Edwards, C., Codd, G.A., 1994. Cyanobacterial (blue-green algal) bloom associated with pathology in brown trout, Salmo trutta L., in Loch Leven, Scotland. J. Fish Dis. 17, 177-181.

Royer, J., Seguineau, C., Park, K.-I., Pouvreau, S., Choi, K.-S., Costil, K., 2008. Gametogenetic cycle and reproductive effort assessed by two methods in 3 age classes of Pacific oysters, Crassostrea gigas, reared in Normandy. Aquaculture 277, 313-320.

Rurangwa, E., Biegniewska, A., Slominska, E., Skorkowski, E.F., Ollevier, F., 2002. Effect of tributyltin on adenylate content and enzyme activities of teleost sperm: a biochemical approach to study the mechanisms of toxicant reduced spermatozoa motility. Comp. Biochem. Physiol. C Pharmacol. Toxicol. Endocrinol. 131, 335-344.

Samain, J.F., Daniel, J.Y., Le Coz, J.R., 1977. Trypsine, amylase et protéines du zooplancton: dosage automatique et manuel. J. Exp. Mar. Biol. Ecol. 29, 279-289.

Shaw, B.L., Battle, H.I., 1957. The gross and microscopic anatomy of the digestive tract of the oyster Crassostrea virginica (Gmelin). Can. J. Zool. 35, 325-347.

Shumway, S.E., Cucci, T.L., 1987. The effects of the toxic dinoflagellate Protogonyaulax tamarensis on the feeding and behaviour of bivalve molluscs. Aquat. Toxicol. 10, 927.

Shumway, S.E., Burkholder, J.A.M., Springer, J., 2006. Effects of the estuarine dinoflagellate Pfiesteria shumwayae (Dinophyceae) on survival and grazing activity of several shellfish species. Harmful Algae 5, 442-458.

Singh, N.P., Muller, C.H., Berger, R.E., 2003. Effects of age on DNA double-strand breaks and apoptosis in human sperm. Fertil. Steril. 80, 1420-1430. 
Smolowitz, R., Shumway, S.E., 1997. Possible cytotoxic effects of the dinoflagellate, Gyrodinium aureolum, on juvenile bivalve molluscs. Aquacult. Int. 5, 291-300.

Soudant P., Marty, Y., Moal, J., Robert, R., Quéré, C., Lecoz, J.R., Samain, J. F., 1996. Effect of food fatty acid and sterol quality on Pecten maximus gonad composition and reproduction process. Aquaculture 143, 361-378.

Soudant, P., Marty, Y., Moal, J., Masski, H., Samain, J.F., 1998. Fatty acid composition of polar lipid classes during larval development of scallop Pecten maximus (L.). Comp. Biochem. Physiol. A 121, 279-288.

Soudant, P., Van Ryckeghem, K., Marty, Y., Moal, J., Samain, J.F., Sorgeloos, P., 1999. Comparison of the lipid class and fatty acid composition between a reproductive cycle in nature and a standard hatchery conditioning of the Pacific Oyster Crassostrea gigas. Comp. Biochem. Physiol. B, Biochem. Mol. Biol. 123, 209-222.

Springer, J.J., Shumway, S.E., Burkholder, J.A.M., Glasgow, H.B., 2002. Interactions between the toxic estuarine dinoflagellate Pfiesteria piscicida and two species of bivalve mollusks. Mar. Ecol. Prog. Ser. 245, 1-10.

Tran, D., Haberkorn, H., Soudant, P., Ciret, P., Massabuau, J.C., 2010. Behavioral responses of Crassostrea gigas exposed to the harmful algae Alexandrium minutum. Aquacutlure. 298, 338-345.

Wildish, D., Lassus, P., Martin, J., Saulnier, A., Bardouil, M., 1998. Effect of the PSP-causing dinoflagellate, Alexandrium sp., on the initial feeding response of Crassostrea gigas. Aquat. Living Resour. 11, 35-43.

Yan, T., Zhou, M., Fu, M., Wang, Y., Yu, R., Li, J., 2001. Inhibition of egg hatching success and larvae survival of the scallop, Chlamys farreri, associated with exposure to cells and cell fragments of the dinoflagellate Alexandrium tamarense. Toxicon. 39, 12391244.

Yan, T., Zhou, M.J., Fu, M., Yu, R.C., Wang, Y.F., Li, J., 2003. Effects of the dinoflagellate Alexandrium tamarense on early development of the scallop Argopecten irradians concentricus. Aquaculture. 217, 167- 178.

Yurchenko, O.V., Radashevsky, V.I., Hsieh, H.L., Reunov, A.A., 2009. Ultrastructural comparison of the spermatozoa of the Pacific oyster Crassostrea gigas inhabiting polluted and relatively clean areas in Taiwan. Aquat. Ecol. 43, 513-519.

Zaldibar, B., Cancio, I., Marigomez, I., 2007. Reversible alterations in epithelial cell turnover in digestive gland of winkles (Littorina littorea) exposed to cadmium and their implications for biomarker measurements. Aquat. Toxicol. 81, 183-196.

Zaldibar, B., Cancio, I., Soto, M., Marigomez, I., 2008 . Changes in cell-type composition in digestive gland of slugs and its influence in biomarkers following transplantation between a relatively unpolluted and a chronically metal-polluted site. Environ. Pollut. $156,367-379$. 


\section{Figure captions:}

Table 1: Effects of microalgal exposure on the intensity of pathological changes in oyster digestive gland, gills and muscle. Results are expressed as mean of stage intensity \pm CI $(n=15)$, with stage $0=$ absence or very light, stage $1=$ moderate and stage $2=$ heavy.

Table 2: Effects of microalgal exposure on the wet weight of digestive glands, protein content and amylase specific activity. Results are expressed as Mean $\pm \mathrm{CI}(\mathrm{n}=3)$.

Fig. 1: An inflammatory response in the intestine of an A. minutum-exposed oyster, with aggregations of hemocytes in the connective tissue surrounding the intestine and hemocytes in diapedesis through the intestine epithelium. Hematoxylin-eosin stained paraffin sections. Intestine (In), gonads (Gn) and digestive tubules (Dt) of $C$. gigas. A. minutum cells (Am), surrounding hemocytes (He-s) and hemocytes in diapedesis (He-d).

Fig. 2: Light inflammatory condition of the intestinal groove presented as aggregation of hemocytes in the connective tissue and diapedesis through intestine epithelium. Hematoxylineosin stained paraffin sections. Style sac (Ss), intestine groove (Ig) and digestive tubules (Dt) of C. gigas. A. minutum cells (Am), surrounding hemocytes (He-s) and hemocytes in diapedesis (He-d).

Fig 3: Different levels/types of myopathy (myodegeneration) observed in muscle of $C$. gigas exposed to A. minutum. Hematoxylin-eosin stained paraffin sections (scale bar $=20 \mu \mathrm{m}$ ). A. healthy muscle fibers in a control oyster; B. myoatrophy with atrophic muscle fibers (arrows); C. wavy pattern degeneration; D. myoatrophy with hyaline degeneration.

Fig. 4: Gills (G) of A. minutum exposed oyster. Mucus (arrows) produced by gills. Hematoxylin-eosin stained paraffin sections (scale bar $=100 \mu \mathrm{m}$ ).

Fig. 5: Neutral lipid and phospholipid contents (mean of 3 pools of 10 oysters each, expressed as mg. $\mathrm{g}^{-1}$ of tissue wet weight, $\pm \mathrm{CI}$ ) in oyster digestive gland according to microalgal exposure. * indicates statistically significant difference between experimental treatments; NS indicates statistically non-significant difference (T-test).

Fig. 6: Monoacylglycerol, diacylglycerol, sterol, free fatty acid, triacylglycerol, ether glycerid and sterol ester contents (mean of 3 pools of 10 oysters each, expressed as mg. $\mathrm{g}^{-1}$ of tissue wet weight, $\pm \mathrm{CI}$ ) in oyster digestive glands according to microalgal exposure. * indicates statistically significant difference between experimental treatments; NS indicates statistically non-significant difference (T-test).

Fig. 7: Lysophosphatidylcholine (LPC), phosphatidylcholine (PC), phosphatidylethanolamine (PE), phosphatidylinositol + ceramide aminoethylphosphonate (PI+CAEP), phosphatidylserine (PS) and cardiolipin (CL) contents (mean of 3 pools of 10 oysters each, expressed as mg. $\mathrm{g}^{-1}$ of tissue wet weight, $\pm \mathrm{CI}$ ) in oyster digestive glands according to microalgal exposure. ${ }^{*}$ indicates statistically significant difference between experimental treatments (T-test).

Fig.8: Percentage of motile spermatozoa (A), ATP content (B), fluorescence intensity of SYBR Green I stained spermatozoa (C), percentage of dead spermatozoa (D), JC-1 monomer 
fluorescence intensity (E) and JC-1 aggregate/monomer ratio (F) of oyster spermatozoa according to microalgal exposures. 


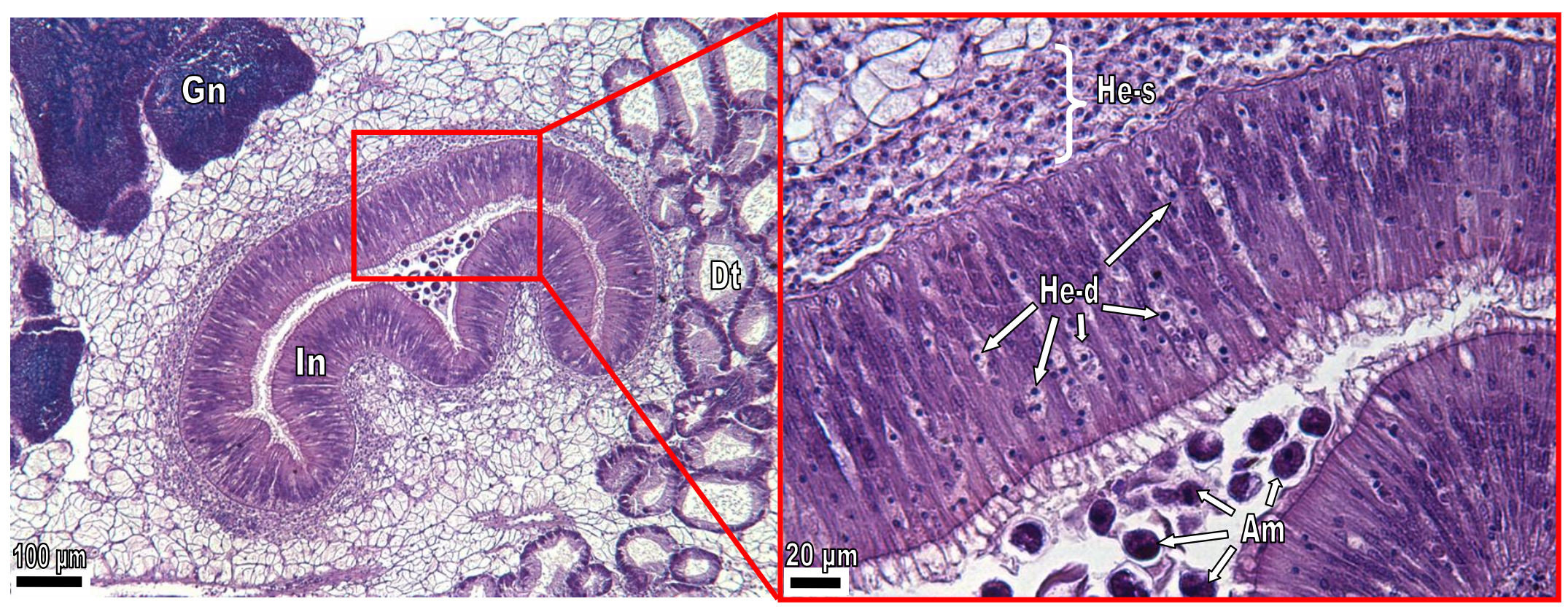

Figure 1 


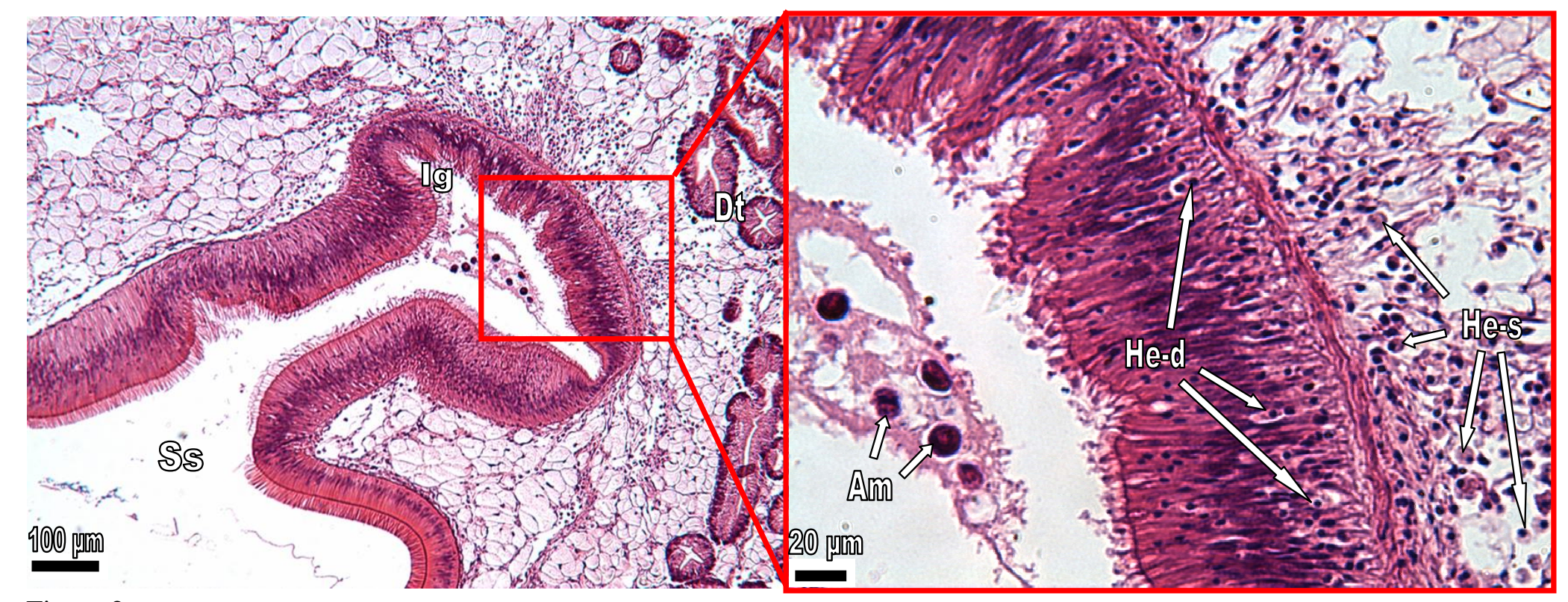

Figure 2 

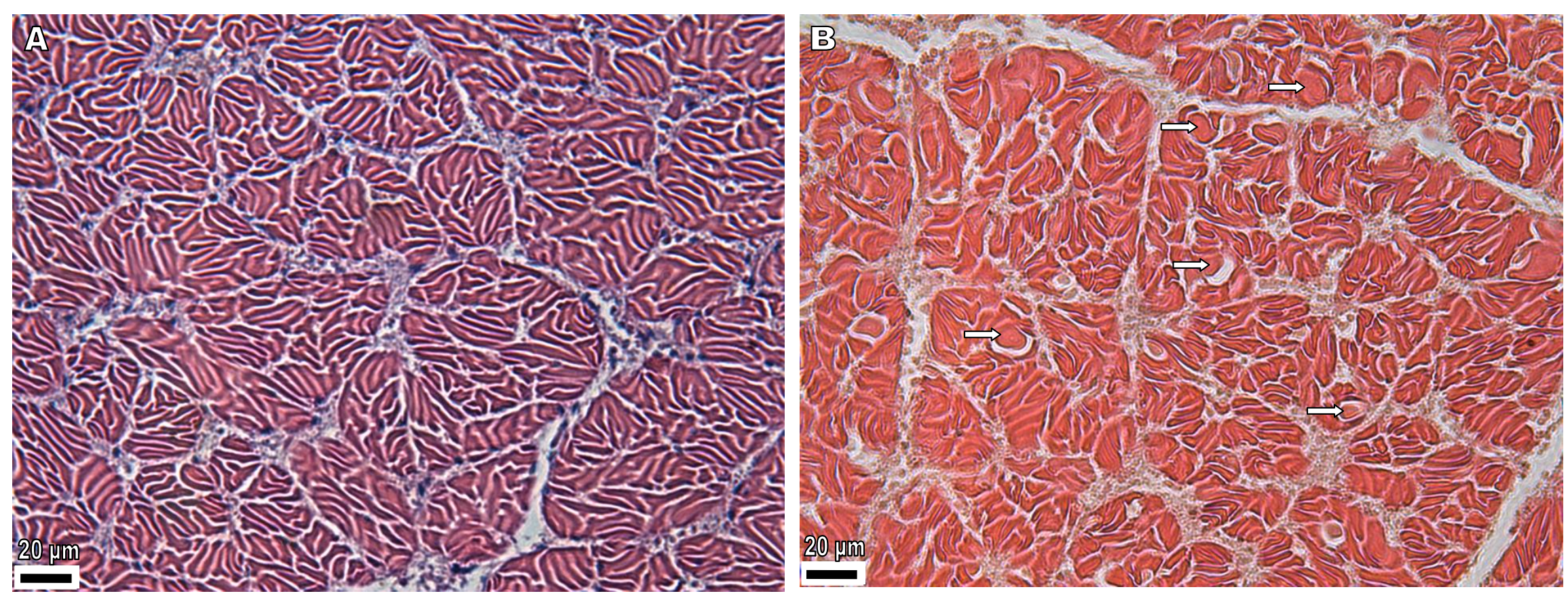

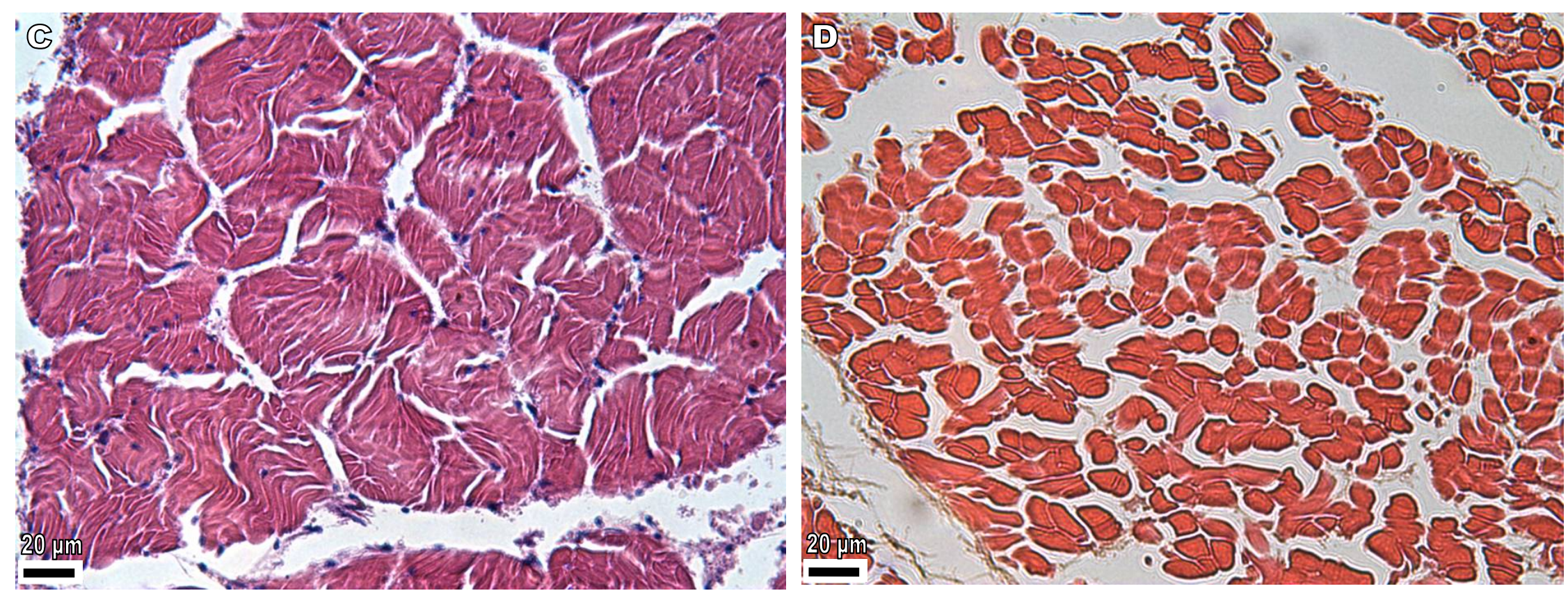

Figure 3 


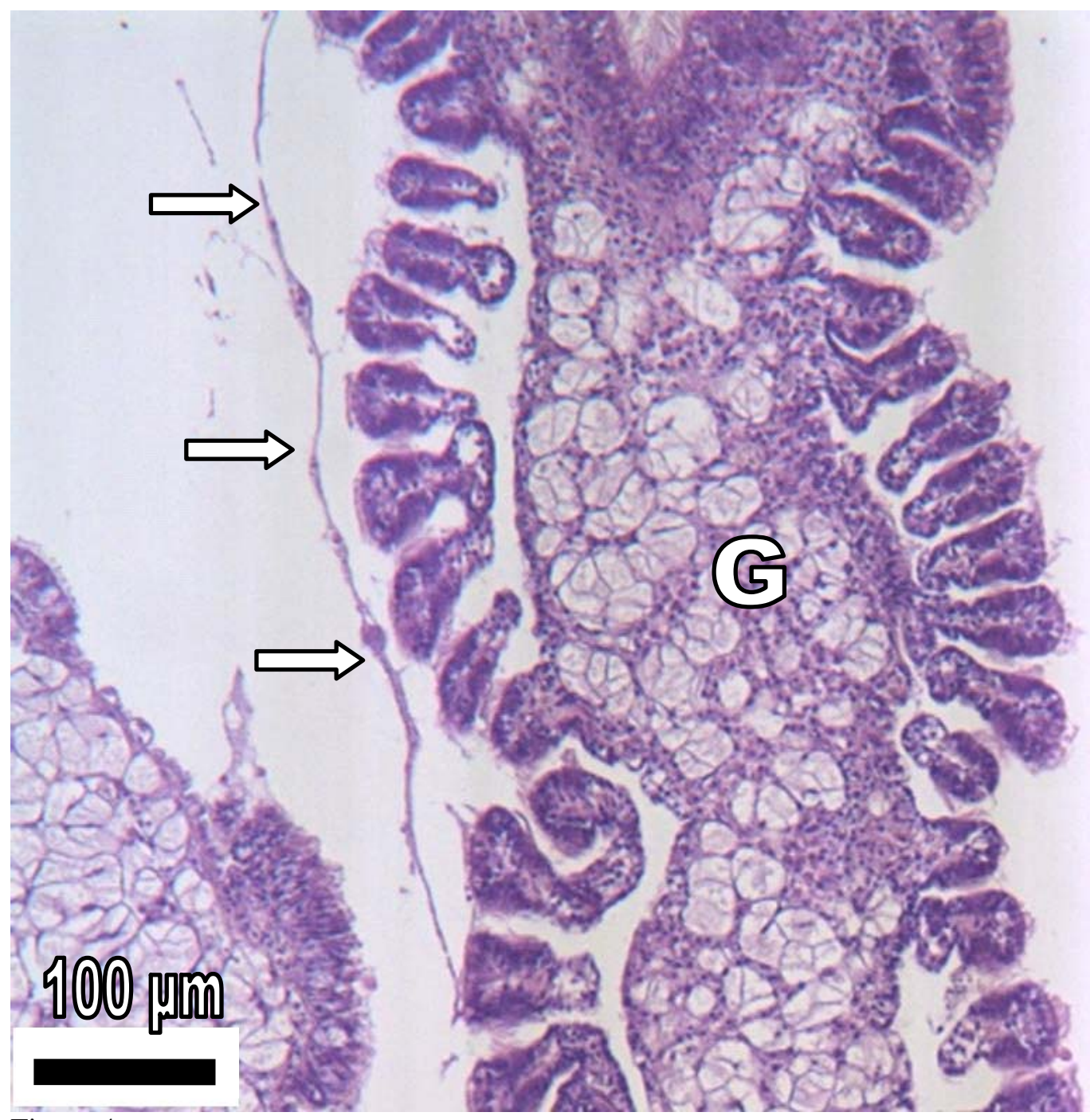

Figure 4 


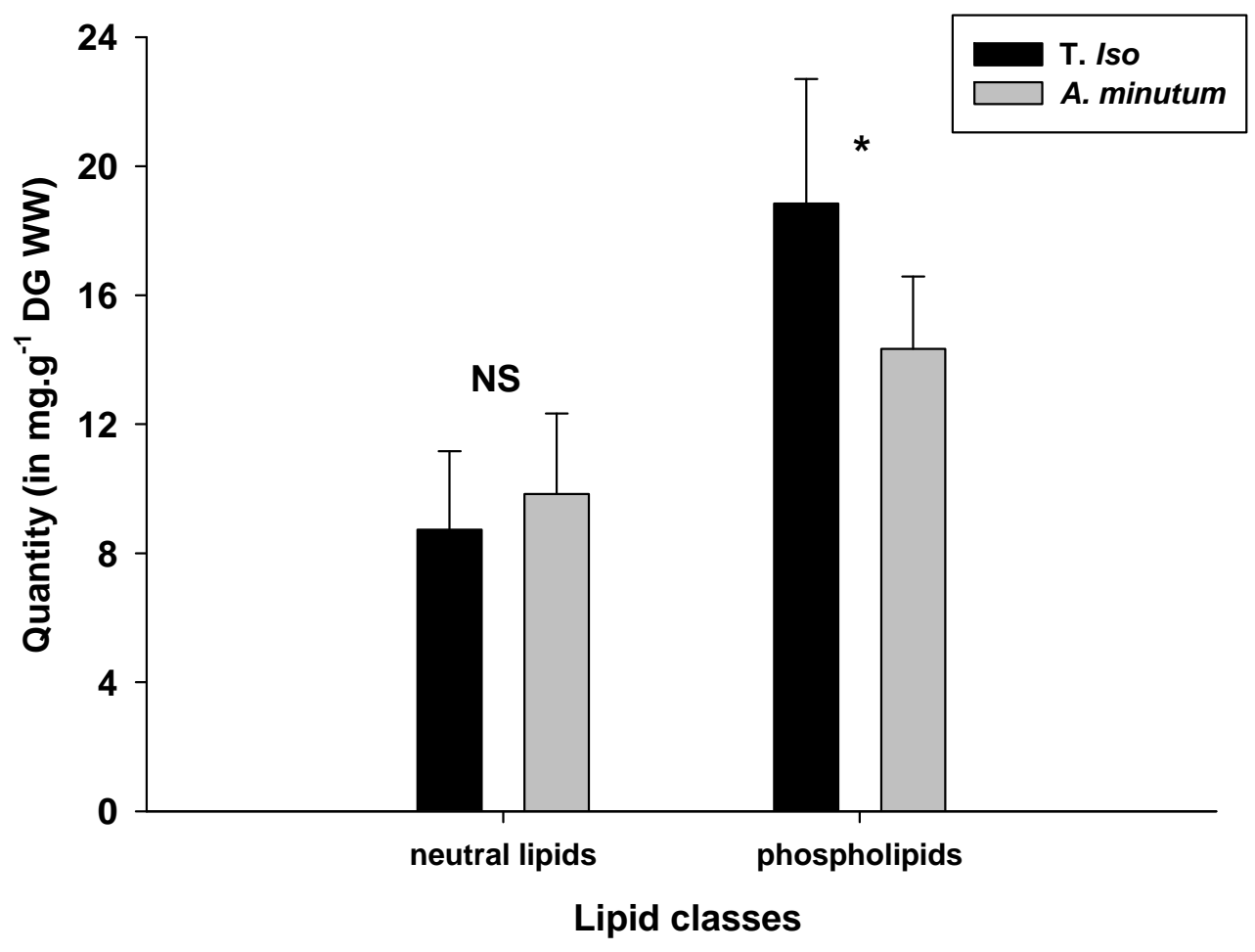

Figure 5 


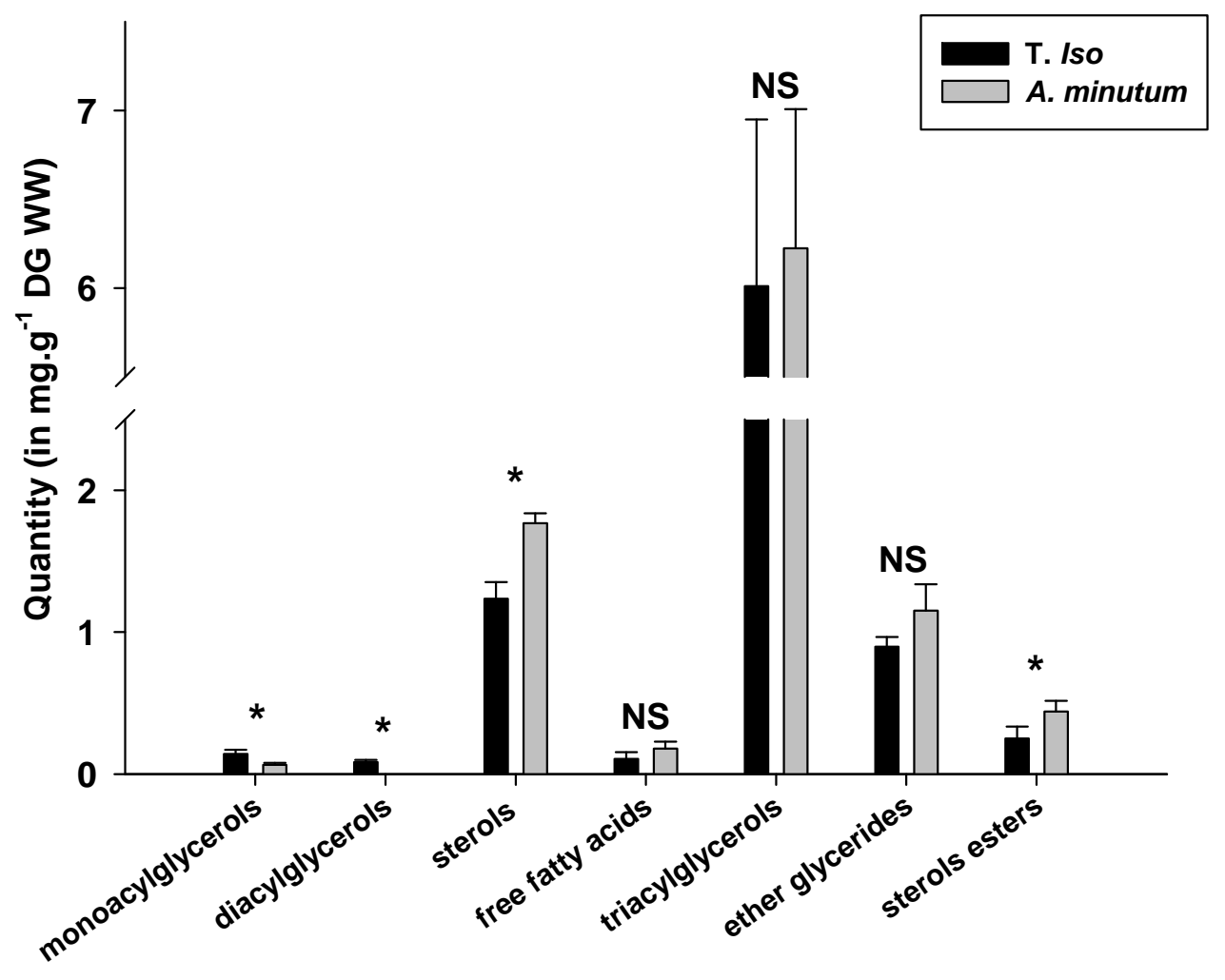

Neutral lipid classes

Figure 6 


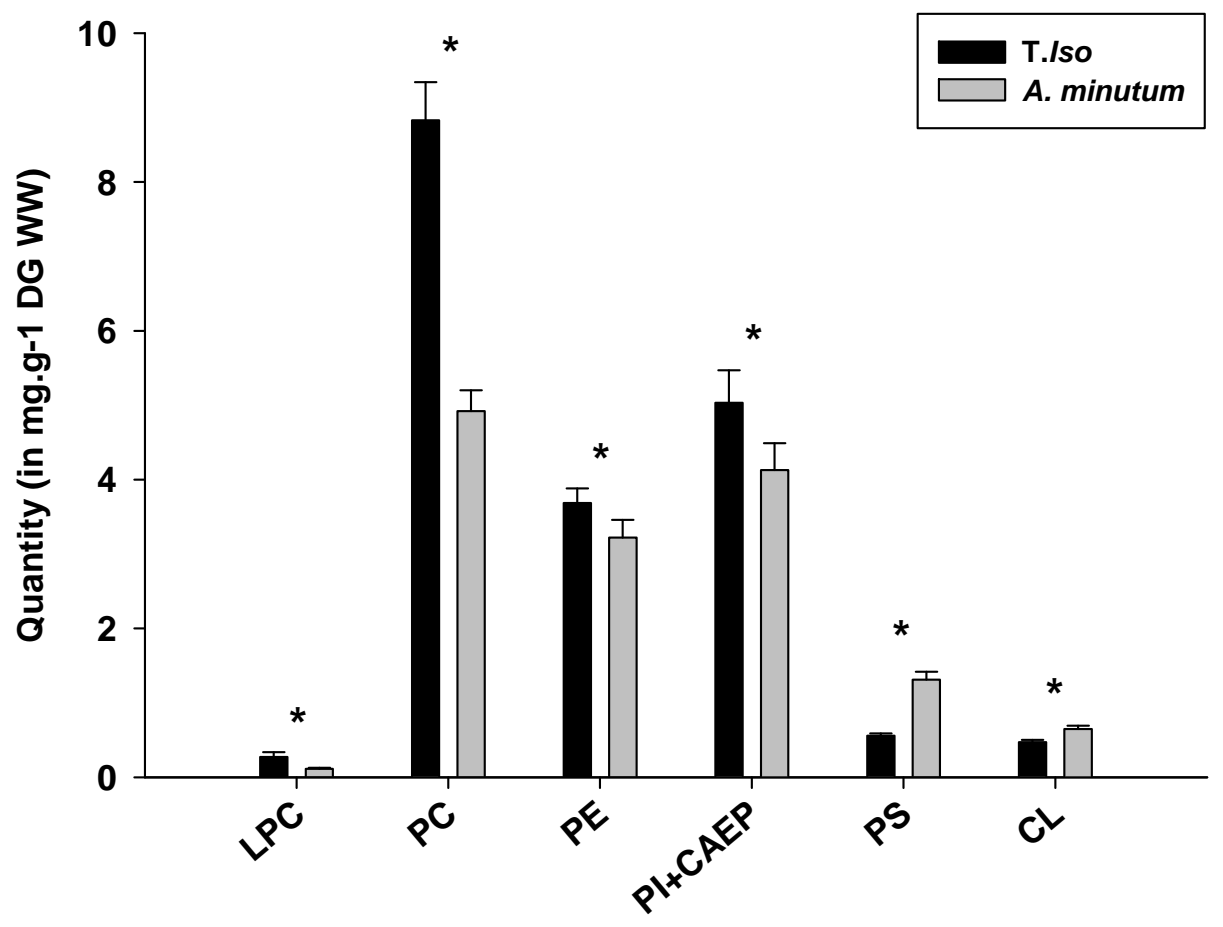

Polar lipid classes

Figure 7 

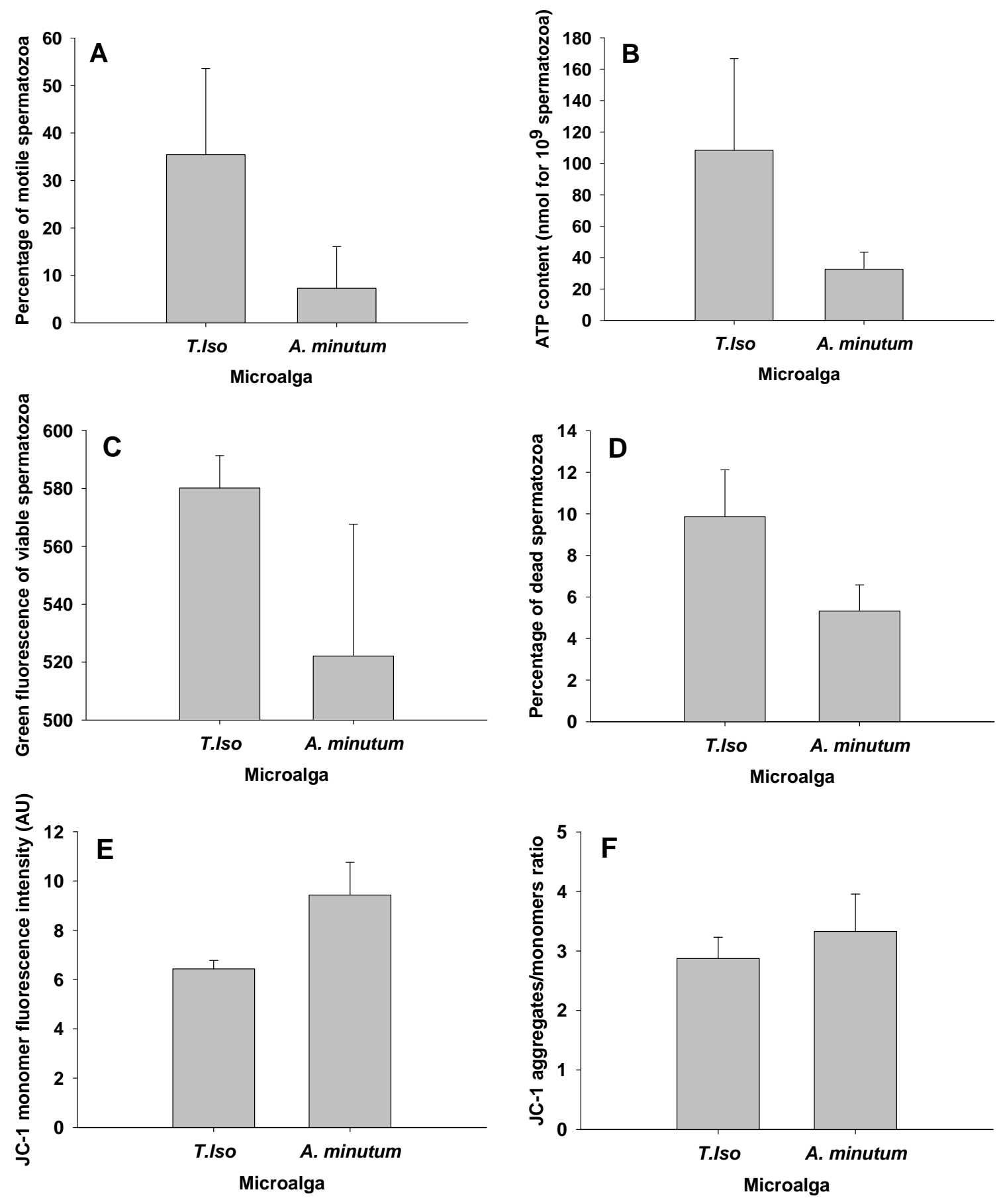

Figure 8 
Table 1

\begin{tabular}{|c|c|c|c|c|}
\hline \multirow[b]{2}{*}{ organ } & \multirow[b]{2}{*}{ variable } & \multicolumn{2}{|c|}{ mean $\pm \mathrm{Cl}$} & \multirow{2}{*}{ U-test } \\
\hline & & A. minutum & T.Iso & \\
\hline \multirow[t]{10}{*}{ digestive gland } & hemocytes surrounding & & & \\
\hline & intestinal groove & $1.07 \pm 0.3$ & $0.3 \pm 0.2$ & ** \\
\hline & intestine & $1.4 \pm 0.3$ & $0.6 \pm 0.3$ & $* *$ \\
\hline & digestive ducts & $0.9 \pm 0.3$ & $0.6 \pm 0.3$ & NS \\
\hline & digestive tubules & $0.5 \pm 0.3$ & $0.4 \pm 0.3$ & NS \\
\hline & hemocytes in diapedesis & & & \\
\hline & intestinal groove & $1.2 \pm 0.2$ & $0.3 \pm 0.3$ & $\star \star \star$ \\
\hline & intestine & $1.4 \pm 0.3$ & $0.5 \pm 0.3$ & 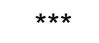 \\
\hline & digestive ducts & $0.7 \pm 0.2$ & $0.3 \pm 0.3$ & * \\
\hline & digestive tubules & $0.3 \pm 0.3$ & $0.06 \pm 0.1$ & NS \\
\hline gills & presence of mucus & $0.9 \pm 0.4$ & $0.1 \pm 0.2$ & ** \\
\hline \multirow[t]{3}{*}{ adductor muscle } & myoatrophy & $1.1 \pm 0.4$ & $0.3 \pm 0.3$ & ** \\
\hline & hyaline degeneration & $0.6 \pm 0.3$ & 0 & $\star \star *$ \\
\hline & wavy pattern degeneration & $0.3 \pm 0.2$ & 0 & NS \\
\hline
\end{tabular}


Table 2

\begin{tabular}{cccc}
\hline & \multicolumn{2}{c}{ mean $\pm \mathrm{Cl}$} & \multirow{2}{*}{ T-test } \\
\hline variables & A. minutum & T.lso & \\
\hline digestive gland wet weight (g) & $0.24 \pm 0.03$ & $0.24 \pm 0.03$ & \\
protein content (mg.g-1 DG WW) & $42.4 \pm 6.4$ & $41.5 \pm 3.3$ & NS \\
amylase specific activity & $0.6 \pm 0.03$ & $0.6 \pm 0.1$ & NS \\
\hline
\end{tabular}

NS : Non-significant differences 